\title{
下北半島尻屋崎の海成段丘における地中レーダー探査
}

\author{
木 村 治 夫*+ 松 浦 旅 人**++ \\ 林泰 幸***市川清 士****
}

\section{Ground Penetrating Radar Profiling beneath a Marine Terrace in the Cape Shiriyazaki, Shimokita Peninsula, NE Japan}

\author{
Haruo KIMURA*+, Tabito MATSU'URA**++, \\ Hiroyuki HAYASHI ${ }^{* * *}$ and Kiyoshi ICHIKAWA****
}

[Received 18 April, 2013; Accepted 9 December, 2014]

\begin{abstract}
The marine isotopic stage (MIS) 5e marine terrace, a paleo-sea-level indicator, is widely distributed at Cape Shiriyazaki, which is located at the northeastern end of Shimokita Peninsula, NE Japan. The elevation of the inner edge of the marine terrace indicates a relative uplift at the site during late Quaternary. However, the marine terrace surface in the study area is covered with colluvium, loess, and soil. Therefore, to reveal the 3-dimensional structure of horizons buried under cover sediments, ground penetrating radar (GPR) profiling was performed across and in parallel to the inner edge on the ground surface. The GPR survey area is about $100 \mathrm{~m}$ across the inner edge and about $200 \mathrm{~m}$ in parallel to the inner edge. Impulse GPR profiling was carried out along nine survey lines above a depth of about $5 \mathrm{~m}$, and stepped frequency modulated continuous wave (FMCW) GPR profiling along nine lines above a depth of about $8 \mathrm{~m}$. GPR data were collected with common-offset modes using the $350 \mathrm{MHz}$ GPR system (Koden Electronics Co., Ltd) for impulse GPR profiling and the 5-160 MHz FMCW GPR system (Kawasaki Geological Engineering Co., Ltd) for FMCW GPR profiling. Furthermore, to estimate the electromagnetic wave velocity used for depth-conversion of GPR sections, the common mid-point (CMP) ensemble composed of 31 scan data was acquired at the site, located at the center of the survey area, with wide-angle measurements. As a result of geological interpretations of depth-converted GPR sections after careful data processing, we obtained the 2-dimensional structures of the boundary horizons between the loess and gravel bed, and the horizons between the gravel bed and bedrock on all GPR sections. We constructed 3-dimensional structures of horizons using these 2 -dimensional structures. The form of the top of the gravel bed is similar to the ground surface
\end{abstract}

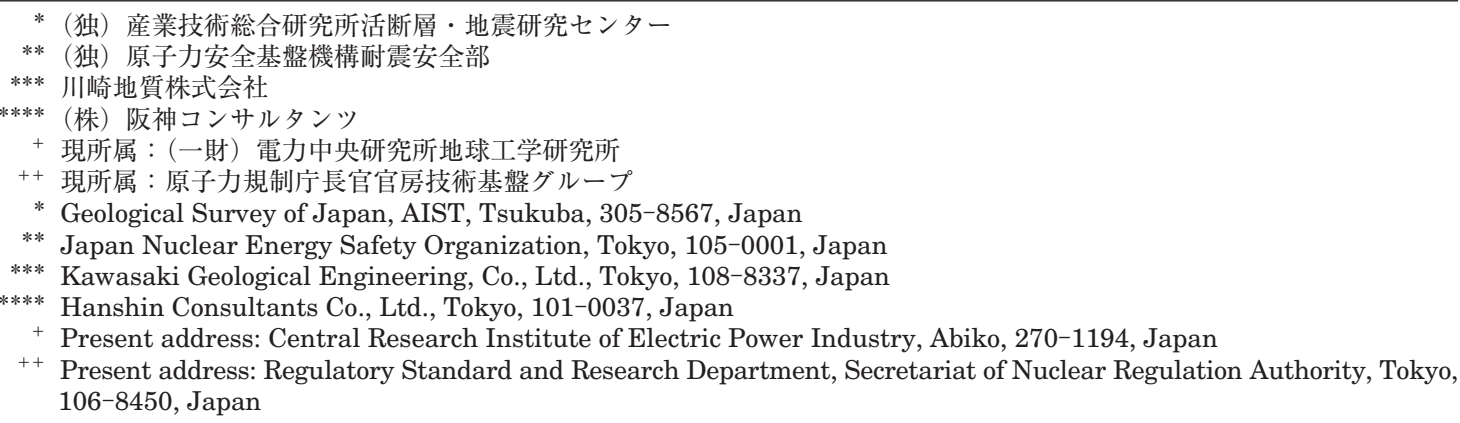


with the exception of a few small areas. Although the top of the bedrock dips a little toward the present coast, the form is almost horizontal. The top of the bedrock probably shows a surface of an uplifted wave-cut platform. The elevations of inner edges inferred from the ground surface, the top of the gravel bed (the bottom of the loess), and the top of the bedrock (the surface of uplifted wave-cut platform) are 32-34 m, 30-32 m, 28-29 m, respectively.

Key words : ground penetrating radar, GPR, shallow subsurface structure, frequency modulated continuous wave radar, FMCW, marine terrace, Cape Shiriyazaki, Shimokita Peninsula

キーワード：地中レーダー（GPR），浅部地下構造，連続波レーダー（FMCW）, 海成段丘，尻屋崎， 下北半島

\section{I. はじめに}

東北日本下北半島（図 1）およびその周辺の 沿岸部には，最終間水期（酸素同位体ステージ MIS 5e : Bassinot et al., 1994, Siddall et al., 2006）に形成された海成段丘が広く分布してい る（例えば, 小池・町田, 2001）。本地域ではそれ らの海成段丘を用いた地殼変動の研究が数多く行 われており，とくに上下変動について，多くの知 見が得られている。例えば Ota（1975）によれ ば，MIS 5e 海成段丘の旧汀線高度分布から，下 北半島地域は大波長の緩やかな変形が卓越する場 と分類されている。さらに，宮内（1990）は同 じくMIS 5e 海成段丘の旧汀線高度分布から，下 北半島を含む津軽海峡周辺の広域地殼変動を検討 し, 東西断面での島弧規模の曲動の存在を指摘 している。また，渡辺ほか (2008) は，下北半島 南部の詳細な MIS 5e 海成段丘面の形状から, 撓 曲変形の存在を指摘し，第四紀後期の逆断層運動 による上下変位量を求めている。このように本地 域では海成段丘調査が第四紀後期の地殼変動像を 求めるにあたって重要な研究手法として用いられ ている。しかし, 上下変位量をはじめとする地殼 変動パラメ夕を定量的かつ高精度に求めるために は，より詳細な海成段丘調査を行うことが望まれ る。

海成段丘の内縁にあたる旧汀線はかつての海水 準を示し，海岸地域における上下変動を明らかに するための重要な地形である（例えば, 太田ほか,
2010)。日本列島で一般に普遍的にみられる海成 段丘はMIS 5e に離水したもので，これらの海成 段丘での旧汀線高度を用いて，地殼変動様式や上 下変動速度が国内の多くの地域で明らかにされて いる（例えば, 太田ほか，2010）。そこで，旧汀線 高度を復元するため, 海成段丘内縁付近の詳細な 地形について注目すると，とくに岩石海岸では海 食崖の基部付近に形成されるノッチなどの地形は 重要な汀線指標となる（例えば, 熊木ほか, 1995）。 しかし，ノッチは岩盤崩壊を誘発しやすいため, 長期間保存されにくい。ノッチのやや下方には, 干潮時には海面上に露出し, 満潮時には水没する ほぼ水平な平坦面である波食棚が分布する。しか し波食棚も, 離水後の堆積物（崩積土, レス, テ フラ，土壤など）によって被覆されて埋没地形と なるために，正確な標高がわかりにくくなる。

そのため, 海成段丘を指標として精度の高い上 下変動量を求める場合, トレンチ・ボーリング掘 削による地質調查や段丘面の開析谷沿いの露頭観 察などによって，被覆層の層厚を把握する必要が ある。さらに, これらの点情報に加えて, 物理探 査によってより広い範囲での連続的な浅層地盤構 造を明らかにすることによって，より詳細な埋没 地形の形状・高度情報が得られると考えられる。 そこで本研究では, 下北半島尻屋崎の MIS $5 \mathrm{e}$ 海 成段丘の内縁付近において，約 $100 \mathrm{~m}$ 強（古海 岸線に直交方向）×約 $200 \mathrm{~m}$ （古海岸線に平行 方向）の範囲で地中レーダー探査を行い，浅層地 盤構造を明らかにすることによって，埋没地形の 


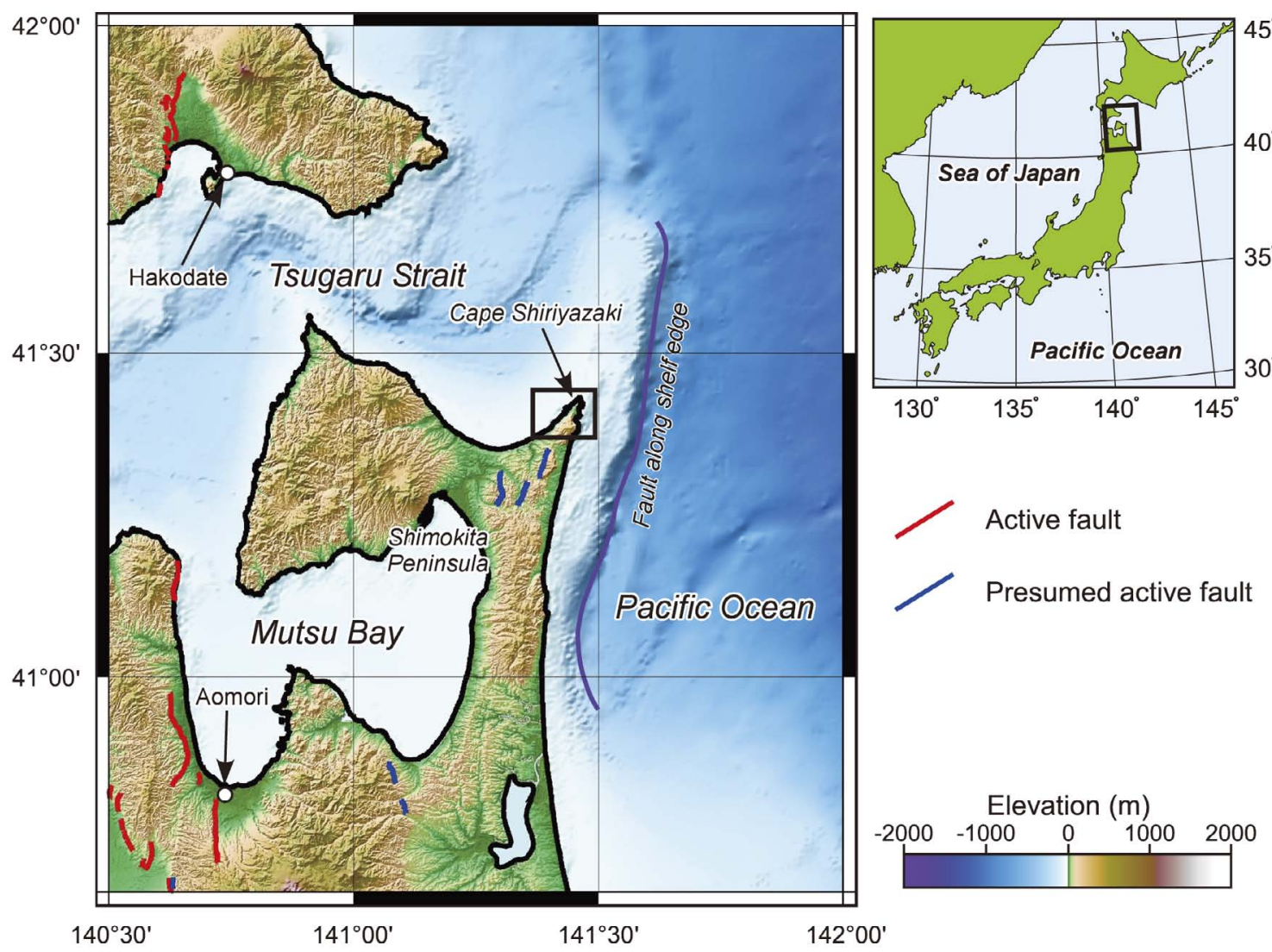

図 1 下北半島周辺地域の地形と活断層の分布. 図の中央，尻屋崎を囲む四角枠は図 2 の範囲を示す。大陸棚外 縁断層の位置は, 活断層研究会（1991）に基づく. 陸域の活断層の位置は中田・今泉（2002）に基づく. 陰影図の光線の向きは北西から南東方向である。陰影図の作成にあたっては, 陸域は国土地理院発行の $50 \mathrm{~m}$ メッシュ標高データを，海域は岸本（2000）の $250 \mathrm{~m}$ メッシュデータを使用した.

Fig. 1 Distribution of active faults and topography in and around the Shimokita Peninsula. The rectangle at the center of the map represents the area of Fig. 2. The location of the submarine fault along the shelf edge is after Research Group for Active Fault of Japan (1991). The locations of active faults are from Nakata and Imaizumi (2002). The light-beam direction in this shaded relief map is from northwest to southeast. The relief map is constructed from a 50-m mesh digital elevation model published by Geospatial Information Authority of Japan (GSI) for land areas and 250-m mesh data from Kishimoto (2000) for sea areas.

形状・高度について検討した。

\section{II. 調查地域の概要}

\section{1）下北半島尻屋崎}

下北半島およびその周辺地域（図 1）は, 日本海 岸沿いに南北の褶曲軸をもつ波長 $100 \sim 150 \mathrm{~km}$ の背斜褶曲（曲動）の東翼に位置しており，東北 地方の日本海側に比べると相対的には隆起量が小
さい地域とされている（宮内, 1990）。しかし, 下北半島のさらに東方沖には大陸棚の東縁に沿っ て明瞭な高度不連続帯がみられ (図 1), 大陸棚 外縁断層（例えば, 活断層研究会, 1991）と呼ば れている。下北半島はこの大陸棚外縁断層の相対 隆起側に位置している。大陸棚外縁断層は日本海 拡大時に活動した主要な正断層のひとつである が，その後の東北日本の東西短縮時には逆断層と 


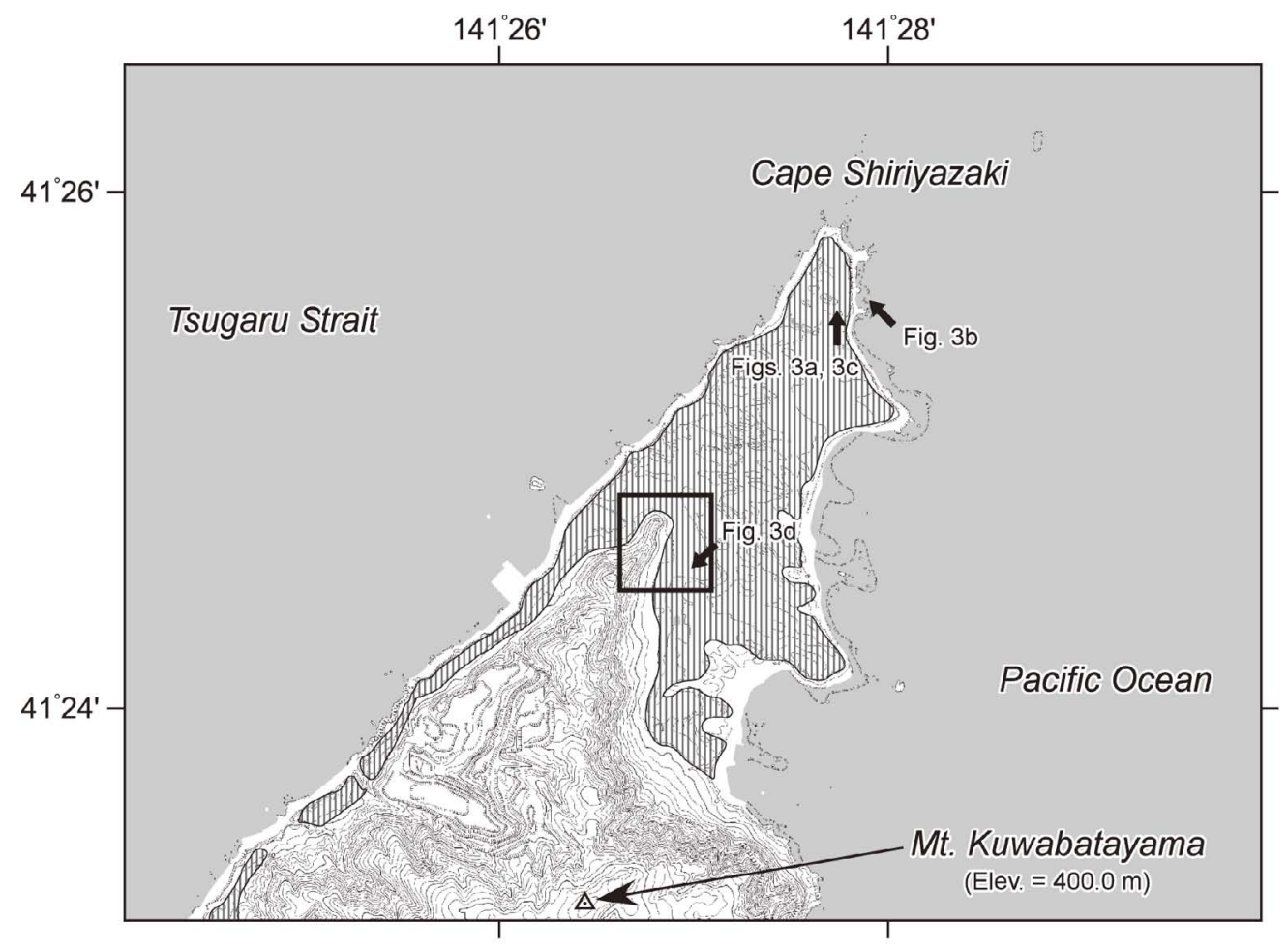

\section{Marine terrace surface (MIS 5e)}

図 2 尻屋崎周辺地域の地形と海成段丘の分布. 図の中央の四角枠は図 4 の範囲を示す。海成段丘の分布は小池・ 町田（2001）に基づく、等高線間隔は $10 \mathrm{~m}$. 基図には, 国土地理院発行の 1:25,000 地形図「尻屋」を用いた.

Fig. 2 Topography and distribution of marine terraces around Cape Shiriyazaki. The rectangle at the center of the map represents the area in Fig. 4. Locations of marine terraces are from Koike and Machida eds. (2001). Contour interval is $10 \mathrm{~m}$. Basemap is "Shiriya" 1:25,000 topographic map published by Geospatial Information Authority of Japan (GSI).

して再活動し，第四紀後期にも活動が継続してい る可能性が指摘されている(池田, 2012)。一方 で, 下北半島の陸域ではいくつかの推定活断層の 存在が指摘されているのみで, 明瞭な活構造は報 告されていない（中田・今泉, 2002）（図 1)。

下北半島北東端の尻屋崎周辺（図 1) では, 標 高 $400 \mathrm{~m}$ の桑畑山を中心とした山地（図 2）に, 中生界ジュラ系付加コンプレックスの尻屋層群 が露出している（松岡, 1987; 脇田ほか, 2009)。 図 2 の範囲外南方では, 尻屋層群を覆って, 中 新世の凝死岩・凝灰質砂岩・シル卜岩・炭質頁岩 からなる猿ヶ森層, 鮮新世の軽石凝死岩・凝灰質
砂岩からなる砂子又層が分布するが，図 2 の範 囲内，桑畑山の北方にはこれらの新第三系は分布 していない（対馬・滝沢, 1977）。図 2 の範囲で は，標高 $15 〜 30 \mathrm{~m}$ に MIS 5e の海成段丘面が 広く分布して扣り (小池・町田, 2001), それら の段丘面をレスや砂丘などが覆っている（対馬・ 滝沢, 1977)。なお, 尻屋崎とその近傍の岩礁で は, 尻屋層群を貫く石英閃緑玢岩の小岩体がみら れる（対馬・滝沢, 1977）。

尻屋崎近傍に分布する MIS 5e 海成段丘は東西 方向に軸をもつ砂丘列に覆われており，その地表 面は平坦ではない。しかしその一方で，尻屋崎近 

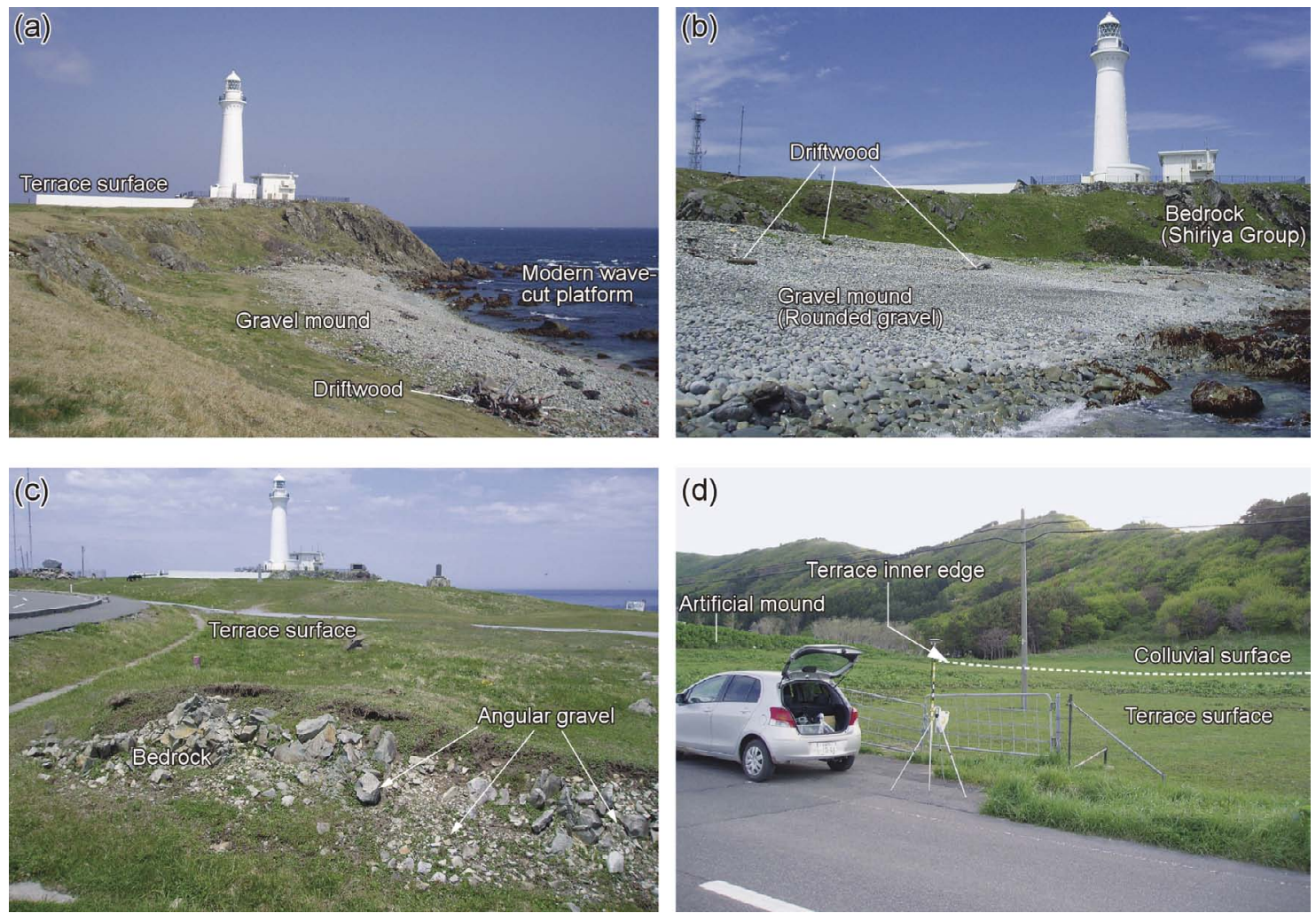

(d)

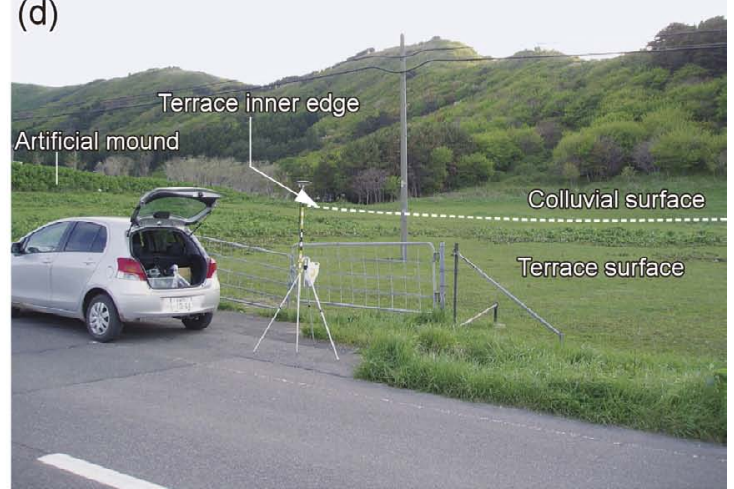

図 3 尻屋崎の海岸と調查測線周辺の写真. Matsu'ura et al. (2014) に加筆. (a) MIS 5e の海成段丘と現生の 海岸地形. 写真右奥には波食棚と汀線アングルがみえるが，手前では高潮位より上に数 $\mathrm{m} の$ 厚さの円䃇 層が堆積している。（b）（a）の手前を拡大した写真（c）段丘構成層の露頭．基盤岩が凍結融解作用によっ て角砂化している。（d）地中レーダー調査地点は海成段丘と崖錐との地表での境界付近に位置している。

Fig. 3 (a) Photographs of the marine terrace (MIS 5e) and the modern coast at Shiriyazaki, modified from Matsu'ura et al. (2014). The modern shoreline angle is buried under gravel accumulated on the wave-cut platform. (b) Closeup of the modern beach showing rounded gravel accumulated on the modern wave-cut platform. (c) An outcrop exposing deposits composing the terrace. Bedrock has been broken into angular gravel by successive freezing and thawing. (d) The GPR survey site is located near the boundary between the terrace and colluvial surfaces.

傍の段丘上では場所によっては風食の影響が激し く, 海成段丘の高度分布把握には注意を要する （対馬・滝沢, 1977）。また, 図 2 の中央南部の山 地の東側には崖錐がよく発達しており，段丘が厚 い斜面堆積物に覆われている。段丘崖は現在の海 岸沿いに分布しており，尻屋層群およびそれを貫 く石英閃緑玢岩といった基盤岩が露出している (図 $3 \mathrm{a} \sim \mathrm{c}$ )。これら海岸沿いの段丘崖の基部に は，円磨された巨礫からなる礫浜がみられ，その 標高は $4 \mathrm{~m}$ 程度に達する（図 $3 \mathrm{a}, \mathrm{b}$ )。この礫浜 の後背域には河川が存在しないことから，礫は河
成堆積物とは考えられず, 暴浪時の海成堆積物 と判断される（例えば, Etienne and Paris, 2010; Matsu'ura et al., 2014）。また, 現在の汀線付近 には基盤岩が露出しており，波食棚が広く形成さ れている(図 3a)。

\section{2）調査地点の浅層地質}

本探査測線に沿って, Matsu'ura et al. (2014) によって, 掘削深度 $7 \sim 8 \mathrm{~m}$ 程度のボーリング $\mathrm{S} 1$ ～ $\mathrm{S} 10$ および掘削深度 $4 \mathrm{~m}$ 程度のボーリング $\mathrm{S} 11$ の，合計 11 本のボーリング掘削調査が行わ れている（図 4)。ここではその結果に基づいて, 

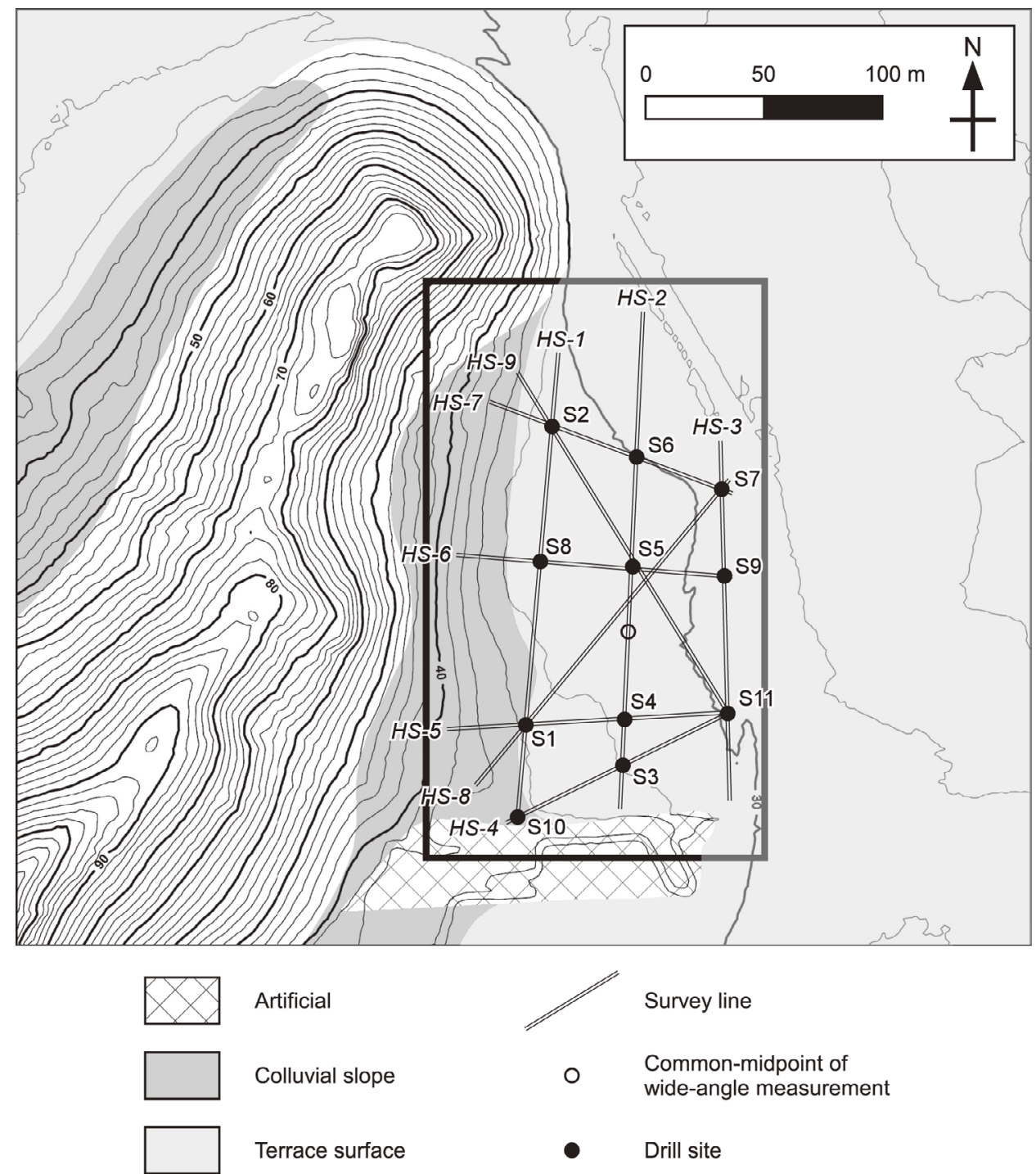

Artificial

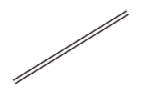

Colluvial slope

0

Survey line

Common-midpoint of

wide-angle measurement

Terrace surface

- Drill site

図 4 地中レーダー探査地点周辺の地形と, 測線およびボーリング掘削地点の詳細位置. 中央の四角枠は図 11 の範囲をあらわす。

Fig. 4 Topography around survey lines of GPR profiling and detailed locations of the survey lines and drilling sites. The rectangle at the center of the map represents the area in Fig. 11.

調査地点の浅層地質層序の概要について述べる。 本調査地点の基盤岩として，地表下深度約 $3.5 \sim$ $6.5 \mathrm{~m}$ 以深で, 固結した泥岩・頁岩がみられ, そ の一部には砂岩やチャートも分布する。これら基 盤岩は調查地域周辺に広く分布する尻屋層群に相 当するものと考えられる。基盤岩の上位には層厚
2 $3 \mathrm{~m}$ 程度の未固結円礫層が分布する。さらに これらは, 層厚 $1 \sim 2 \mathrm{~m}$ 程度のレスによって覆わ れている。一部のレスには角礫が混じっている。 最上位には盛土がみられる場所を除いて，層厚 $1 \mathrm{~m}$ 未満の黒ボク土が分布している。また，ボー リング掘削地点が分布していないため地下地質の 
詳細は不明であるが，測線群の西端付近には崖錐 堆積物が分布しており (図 3d, 図 4), その最上 部はレス・土壤によって覆われている。

\section{III. 地中レーダー探査}

\section{1）探查測線}

本研究における地中レーダー探査測線群は, 下 北半島尻屋崎周辺に分布する MIS 5e 海成段丘面 の内縁付近に位置する。これらの詳細位置を図 4 に示す。これらの探査測線分布域では Matsu'ura et al.（2014）によって S1〜 S11（図 4）の 11 本のボーリング掘削が行われたが，掘削時の地下 水流出は記録されていない。調查時期が厳冬期で あったこと, 集水域がきわめて小さいことから, ボーリング掘削深度（地表下 $7 \mathrm{~m}$ ) 以浅において は地下水の影響はほとんどないと考えられる。探 査測線群は，海成段丘と崖錐との境界とほぼ直交 する HS-5 HS-7 の 3 本の測線（測線長はそれ ぞれ，120 m, $118 \mathrm{~m}, 110 \mathrm{~m}$ ), 上記境界とほぼ 平行な HS-1 〜 HS-3 の 3 本の測線（測線長はそ れぞれ $198 \mathrm{~m}, 212 \mathrm{~m}, 152 \mathrm{~m})$ ，これらとは斜交 するが，先述したボーリングの対比を主目的とし た HS-4，HS-8，HS-9 の 3 本の測線（測線長は それぞれ，105 m, $169 \mathrm{~m}, 170 \mathrm{~m})$, 合計 9 測線 によって構成される。また，測線分布のほぼ中央 にあたる, HS-2 測線の南端から $75 \mathrm{~m}$ の地点に, 地中電磁波速度推定のためのワイドアングル測定 （例えば, 物理探査学会, 1998）の測定点を設定し た（図 4 中の白丸）。

本研究では, 地表下深度約 $5 \mathrm{~m}$ までは比較的 高分解能な探査断面の取得を目標とし，かつ，地 表下深度約 $5 \mathrm{~m}$ 以深でも大局的な構造のイメー ジングも可能にすることを目標とした。やや分解 能が低下しても，より深部までの探査を可能にす るためには，より低周波の電磁波を用いることが 有効である（Davis and Annan, 1989; Smith and Jol, 1995)。極浅部の高分解能探査としてインパ ルス地中レーダー探査（例えば, 物理探査学会, 1998; Daniels, 2007）を高周波数帯域で（表 1), 深部までの大局的な探査としてステップ式連続波 地中レーダー探査（例えば, Iizuka et al., 1984;
表 1 インパルス地中レーダー探査のデータ 取得パラメ夕.

Table 1 Acquisition parameters for impulse GPR data.

\section{Instruments}

\section{GPR-10C}

(Koden Electronics Co., Ltd.)

\section{Scanning}

Frequency

No. of scan points

$350 \mathrm{MHz}$

9901 (HS-1P), 10601 (HS-2P), 7601 (HS-3P), 5251 (HS-4P), 6001 (HS-5P), 5901 (HS-6P), 5501 (HS-7P), 8451 (HS-8P), 8501 (HS-9P)

Scan point interval $0.02 \mathrm{~m}$

No. of scans /

1 scan point

8

\section{Recording}

No. of samples $\quad 400$

Sampling intervals $0.45 \mathrm{~ns}$

Recording length $179.55 \mathrm{~ns}$

Daniels, 2007）を低周波数帯域で（表 2)，とい う異なる 2 つ仕様の地中レーダー探査を行っ た。インパルス地中レーダー探査およびステップ 式連続波地中レーダー探査は，ともに HS-1 HS-9 の各測線において，同じ測線上で行った。 本稿のこれ以降では，例えば，HS-1 測線でのイ ンパルス地中レーダー探査を HS-1P，ステップ 式連続波地中レーダー探查を HS-1C というよう に，違いを区別して記述する。

\section{2) データ取得}

インパルス地中レーダー探査のデータ取得に おけるおもな仕様を，表 1 に示す。データ取得 はプロファイル測定法（例えば, 物理探査学会, 1998）によって行った。探査で用いた測定シス テムは (株) 光電製作所製の GPR-10C であり, 送受信アンテナも一体型のシステムとなってい る。本探査での中心周波数は $350 \mathrm{MHz}$ である。 ここで，地表付近を構成する地層の電磁波速度は $0.05 \sim 0.2 \mathrm{~m} / \mathrm{ns}$ (Neal, 2004)，反射法探查にお ける鉛直分解能は 4 分の 1 波長であること（例 えば, Sheriff and Geldart, 1995）から，上記周 
表 2 ステップ式連続波地中レーダー探査のデータ取 得パラメタ.

Table 2 Acquisition parameters for stepped frequency modulated continuous wave GPR data.

\section{Instruments}

Stepped FM-CW GPR system

(Kawasaki Geological Engineering Co., Ltd)

(Kasai et al., 1996; Suzuki et al., 1999)

\section{Scanning}

Frequency

No. of scan points

5-160 MHz (upward)

397 (HS-1S), 425 (HS-2S),

305 (HS-3S), 211 (HS-4S),

241 (HS-5S), 237 (HS-6S),

221 (HS-7S), 339 (HS-8S),

341 (HS-9S),

31 (wide-angle measurement)

$\mathrm{Tx}-\mathrm{Rx}$ *

$3.0 \mathrm{~m}$ (profile measurement)

3.0-9.0 m (wide-angle measurement)

Scan point interval $0.5 \mathrm{~m}$ (profile measurement),

$0.2 \mathrm{~m}$ (offset increment in wide-angle measurement)

No. of scans / $\quad 100$

1 scan point

\section{Recording}

No. of samples $\quad 256$

Sampling intervals $2.52 \mathrm{~ns}$

Recording length $642.6 \mathrm{~ns}$

* Offset between the transmitter and receiver.

波数に対応する鉛直分解能は $0.1 \mathrm{~m}$ 程度と期待さ れる。

次に, ステップ式連続波地中レーダー探査の デー夕取得におけるおもな仕様を，表 2 に示す。 ステップ式連続波地中レーダー探査では，プロ ファイル測定に加えて, 地中電磁波速度推定のた めのワイドアングル測定も行った。探査で用いた 測定システムは川崎地質株式会社によって製作 されたもので，その詳細は笠井ほか（1996）や 鈴木ほか（1999）などによって報告されている。 ステップ式連続波地中レーダー探査では送信信号 の周波数を低域から高域に向けて変化させる。そ の際の周波数変化の状況は図 5 のような階段状 (ステップ式) の変化である。この方法によれば, 送信アンテナから瞬間的に大電力を送ることな

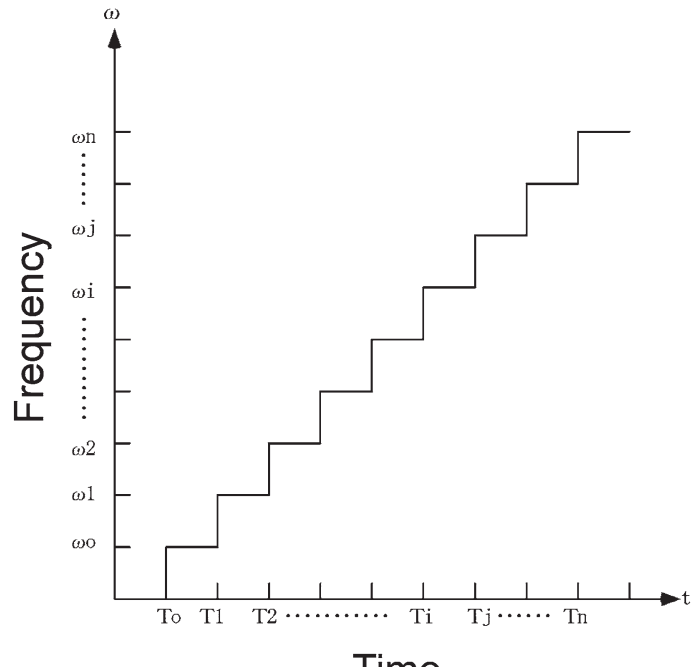

Time

図 5 本研究における連続波地中レーダー探査で用 いられているステップ式掃引方法の概念図. 笠井ほか（1996），鈴木ほか（1999）に加筆.

Fig. 5 A schematic diagram showing stepped frequency modulation used in the survey, modified from Kasai et al. (1996) and Suzuki et al. (1999).

く，送信時間を長くすることによって，結果とし て送信アンテナから大きなパワーをもつ電磁波を 送り出すことができる。ステップ式連続波地中 レーダー探査ではより深部の構造を大局的に求め るために，インパルス地中レーダー探査で用いた 中心周波数よりも低い $5 \sim 160 \mathrm{MHz}$ の周波数帯 域の掃引波形を用いた。

ステップ式連続波地中レーダー探査では 1 地 点あたり 100 回のスキャンを行い，それらをス タックすることにより $\mathrm{S} / \mathrm{N}$ 比の向上をはかった。 この回数は，極浅部を対象としたインパルス地中 レーダー探査 (8 回)よりも大幅に増やしており, より深部までのイメージングを目標としている。

また，探査測線の水平位置・標高值の決定のた めに探査測線およびその周辺で測量を行った。ま ず，国際航業株式会社所有の航空 LIDAR デー夕 から本地域の $2 \mathrm{~m}$ メッシュ標高データを作成し た。その上で, $\mathrm{S} 1$ ～S11のボーリング掘削地点 との位置関係を明確にするためにリアルタイムキ ネマティック GPS システムによる測量を行った。 
表 3 インパルス地中レーダー探査のデータ処理一覧.

Table 3 Processing sequence for impulse GPR data.

\begin{tabular}{ll}
\hline Automatic gain control & Window: $45 \mathrm{~ns}$ \\
Bandpass filter & 100-300 $\mathrm{MHz}$ \\
(Velocity analysis) & Common mid-point analysis \\
NMO* correction $^{*}$ & \\
Migration & \\
Depth conversion & (See Table 5 for velocity) \\
Elevation statics & \\
\hline
\end{tabular}

* NMO: Normal moveout.

さらに，地中レーダー探査測線に沿って約 $0.5 \mathrm{~m}$ おきにレベル測量を行い, 詳細な標高值を得た。

\section{3) データ処理}

インパルス地中レーダー探査, ステップ式連続波 地中レーダー探査ともに，データ処理は Heesong Geotek Co., Ltd. 製の地中レーダー探査データ処 理ソフトウェア RADPRO を用いて行った。イン パルス地中レーダー探査で取得したデータに施し た処理の一覧を表 3 に，ステップ式連続波地中 レーダー探査のプロファイル測定で取得したデー 夕に施した処理の一覧を表 4 に示す。これら各 種のフィルター処理や振幅回復・調整処理を行 い, 地中レーダー探査の時間断面を得た。

ここで，時間断面の normal moveout（NMO） 補正処理, マイグレーション処理, 深度変換処理 を行うにあたって, 地中電磁波速度の情報が必要 となる。そのため, ステップ式連続波地中レー ダー探査のワイドアングル測定（探査地点は図 4 中の丸印)によって取得した共通中間点 (common mid-point : CMP) アンサンブルデータ（図 6a） を解析することにより, 地中電磁波速度を求め た。一般的に反射波は CMP アンサンブルでは, 上に凸の双曲線状の波列としてみられる。図 $6 \mathrm{a}$ でわかるように，この探査地点では多くの明瞭な 反射波列が記録されているが，そのなかでも特徵 的なものを $\mathrm{R} 1 \sim \mathrm{R} 4$ として図 $6 \mathrm{a}$ 中に示す。こ のデータについて定速度重合による速度解析を 行った結果を図 $6 \mathrm{~b}$ および表 5 に示す。

図 $6 \mathrm{~b}$ 中に濃い赤色として表示されている箇所 は，重合処理後に振幅が大きくなる RMS 速度一
表 4 ステップ式連続波地中レーダー探査のデータ 処理一覧.

Table 4 Processing sequence for stepped frequency modulated continuous wave GPR data.

Delete mean trace

Automatic gain control Window: $150 \mathrm{~ns}$

Bandpass filter 30-90 $\mathrm{MHz}$

Deconvolution filter

Automatic gain control Window: $300 \mathrm{~ns}$

Velocity analysis

Common mid-point analysis

NMO* correction

Migration

Depth conversion (See Table 5 for velocity)

Elevation statics

* NMO: Normal moveout.

往復走時のペアを示している。眓 $6 \mathrm{~b}$ 中のV1で 示される往復走時 $55 \mathrm{~ns}, \mathrm{RMS}$ 速度 $0.0871 \mathrm{~m} / \mathrm{ns}$ [第一層の比誘電率 $\varepsilon_{\mathrm{r}}=11.85$ ] 周辺の領域が他 に比べて定速度重合パネル中での振幅が周囲に 比較してとくに大きく，この付近の RMS 速度一 往復走時ペアは図 $6 \mathrm{a}$ 中の反射波 $\mathrm{R} 1 \sim \mathrm{R} 2$ に対 応している。さらに深度が深い（往復走時が大き い）領域での速度解析を行ったが，振幅が最も強 くなる部分であわせると速度が遅くなりすぎ，区

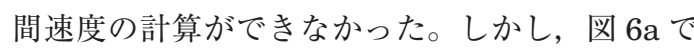
わかるように急な角度の走時曲線の陰に少し傾斜 が緩やかなものがみえ，それらは図 $6 \mathrm{~b}$ で振幅が やや強くなる領域に相当する。そこで，図 $6 \mathrm{~b}$ 中 の V2 およびV3 で示される RMS 速度を読み取 り，その妥当性について，ワイドアングル測定地 点近傍のボーリング $\mathrm{S} 4$ および S5（図 7）と比較 することにより確認した。

V1（図 6b）の読み取り值（55 ns，0.0871 m/ $\mathrm{ns}$ [比誘電率 $\varepsilon_{\mathrm{r}}=11.85$ ]) では地表下深度が $2.40 \mathrm{~m}$ （表 5）となり，ボーリングデー夕（図 7) ではレス層の基底付近に相当すると考えられる。 また，反射波列 R4（図 6a）に対応するV3（図 6b) の読み取り值 $(146 \mathrm{~ns}, 0.0680 \mathrm{~m} / \mathrm{ns})$ では 地表下深度が $4.81 \mathrm{~m}$ （表 5) となり，ボーリング デー夕（図 7）では基盤岩上面に相当すると考え られる。なお，反射波列 R3（図 6a）に対応する 


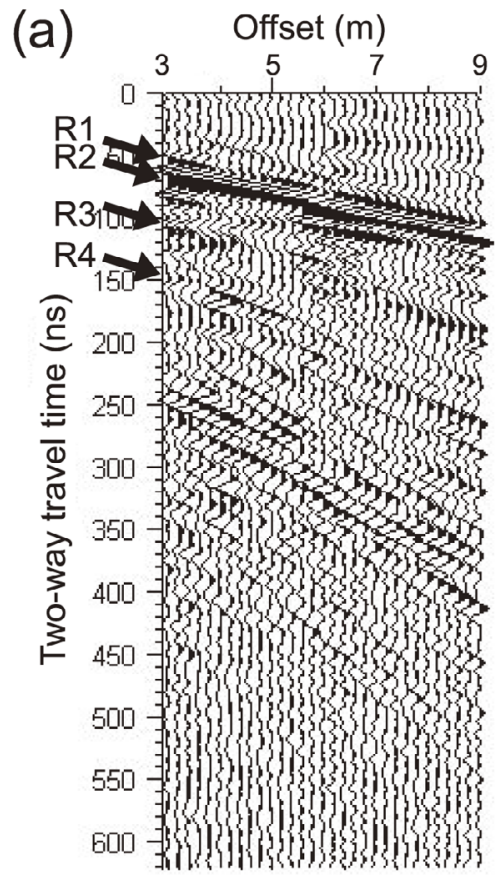

(b)

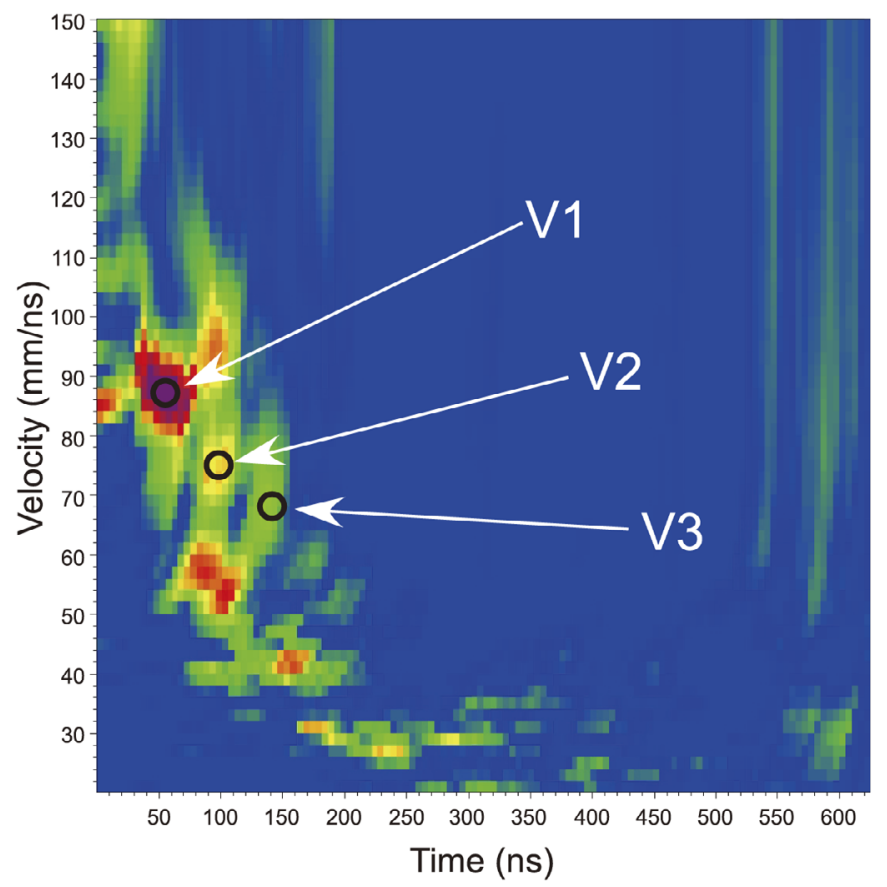

図 6 ワイドアングル測定による速度解析.（a）HS-2 測線上の南端から $75 \mathrm{~m}$ 地点における共通中間点（CMP） アンサンブル．R1〜 4 の矢印は顕著な反射を示す。（b）速度解析結果．丸印は二乗平均 (RMS) 速度を示す.

Fig. 6 Velocity analysis using wide-angle measurements. (a) Common-midpoint (CMP) ensemble at the site, located 75 $\mathrm{m}$ north from the southern end on line HS-2. Arrows R1-4 show reflections. (b) Results of analysis using velocity semblance spectra at the CMP. Open circles indicate root-mean-square (RMS) velocities.

表 5 速度解析の結果.

Table 5 Results of velocity analysis.

\begin{tabular}{ccccc}
\hline Time $(\mathrm{ns})$ & RMS velocity $(\mathrm{m} / \mathrm{ns})$ & Interval velocity $(\mathrm{m} / \mathrm{ns})$ & $\varepsilon_{\mathrm{r}}$ & Depth $(\mathrm{m})$ \\
\hline 0 & & & 11.85 & 0 \\
55 & $0.871(\mathrm{~V} 1)$ & 0.871 & 27.57 & 2.40 \\
100 & $0.751(\mathrm{~V} 2)$ & 0.571 & 37.13 & 3.68 \\
146 & $0.680(\mathrm{~V} 3)$ & 0.492 & & 4.81 \\
\hline
\end{tabular}

V1, V2, V3: See Fig. 6b.

V2（図 6b）では深度が $3.68 \mathrm{~m}$ となり，礫層内 に相当することから，礫層中に反射を生じるよう な特徵的な面の存在が示唆される。S4 および S5 ボーリングでは記録されていないが，他のボーリ
ングでは礫層中で，ローム質の基質に細礫および $10 \mathrm{~mm}$ 以下の中礫が厚さ $0.15 \mathrm{~m}$ で分布している ものもあり，このような礫層内の特徽的な地層面 が地中レーダー記録に現れたものと考えられる。 


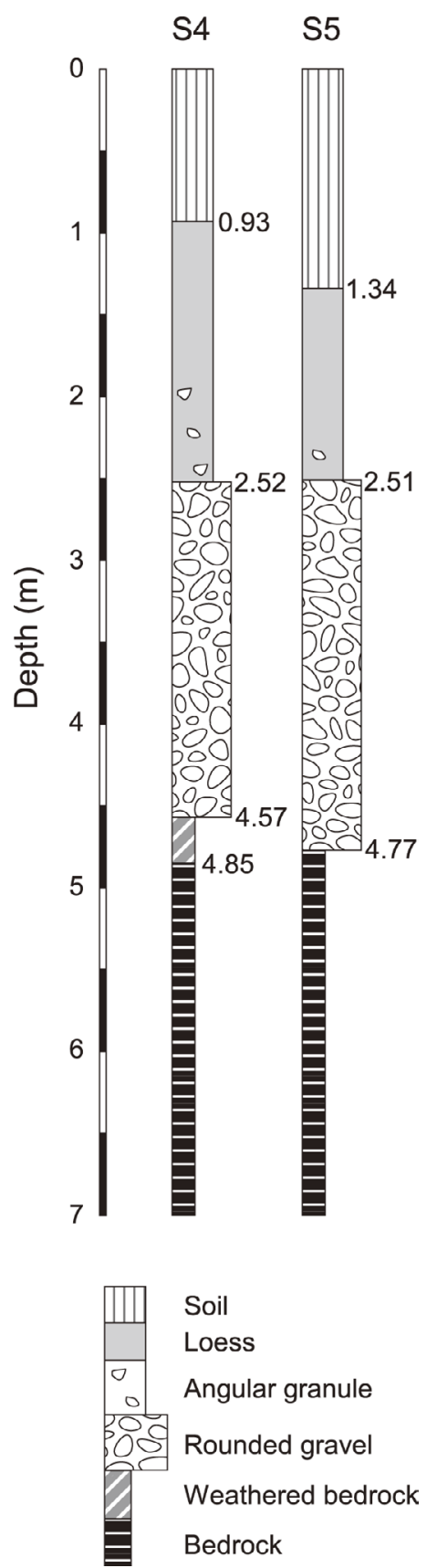

図 7 S4 および S5 ボーリング柱状図 (Matsu'ura et al., 2014).

Fig. 7 Stratigraphy of drill-cores at S4 and S5 (Matsu'ura et al., 2014).
以上から表 5 で示される速度解析結果は本探査 地域の地層に対応したものであると判断し, normal moveout (NMO) 補正処理，マイグレーショ ン処理，深度変換処理に用いた。ただし，ここで 得られた地中電磁波速度は調査範囲全体を代表す るものとして，探査測線群のほぼ中央で計測した ものであり, 調査範囲内の他の部分では地中電磁 波速度が変化している可能性も考慮し, 深度変換 断面の解釈にあたってはボーリング掘削デー夕等 も利用して慎重に行わなければならない。

以上によって, インパルス地中レーダー探査, ステップ式連続波地中レーダー探査ともに，各探 査測線の深度变換断面を得た。

\section{IV. 探査断面の地質学的解䣋}

得られたインパルス地中レーダー探査とステッ プ式連続波地中レーダー探査それぞれ 9 測線, 合 計 18 測線の深度変換断面について地質学的解釈 を行った。解釈にあたっては先述した $\mathrm{S} 1$ ～S11 のボーリングデータを参考とし，それらでみられ た各掘削地点での地層境界深度をリファレンスポ イントとした。また，インパルス地中レーダー探 查断面とステップ式連続波地中レーダー探査断面 を組み合わせてお互いを参考として解釈を進めた （例えば，HS-1P 断面と HS-1C 断面，HS-2P 断 面と HS-2C 断面といった組み合わせ)。ただし， 今回のステップ式連続波地中レーダー探査では地 表下深度約 $2 \mathrm{~m}$ 以浅の分解能が非常に低いため, この深度領域ではインパルス地中レーダー探査の 結果を重視した。さらに各測線の交点では，解釈 ホライゾンの深度がそれぞれの断面でほぼ一致す るように解釈を行った。

ここでは, 計 18 測線で構成される本探査測線群 のうち，これらを代表する特徵をあらわしている 以下の測線をとりあげる。まず，探査範囲の中央 やや南方に位置し, 海成段丘と崖錐の地表での境 界（図 3d，図 4）と直交する HS-5P 測線および HS-5C 測線の断面（図 8, 測線位置は図 4 参照) について詳細を述べる。さらに，探査範囲の中央 に位置し，上記の HS-5 測線と直交する南北方向 の HS-2P 測線および HS-2C 測線の断面（図 9, 
(a)
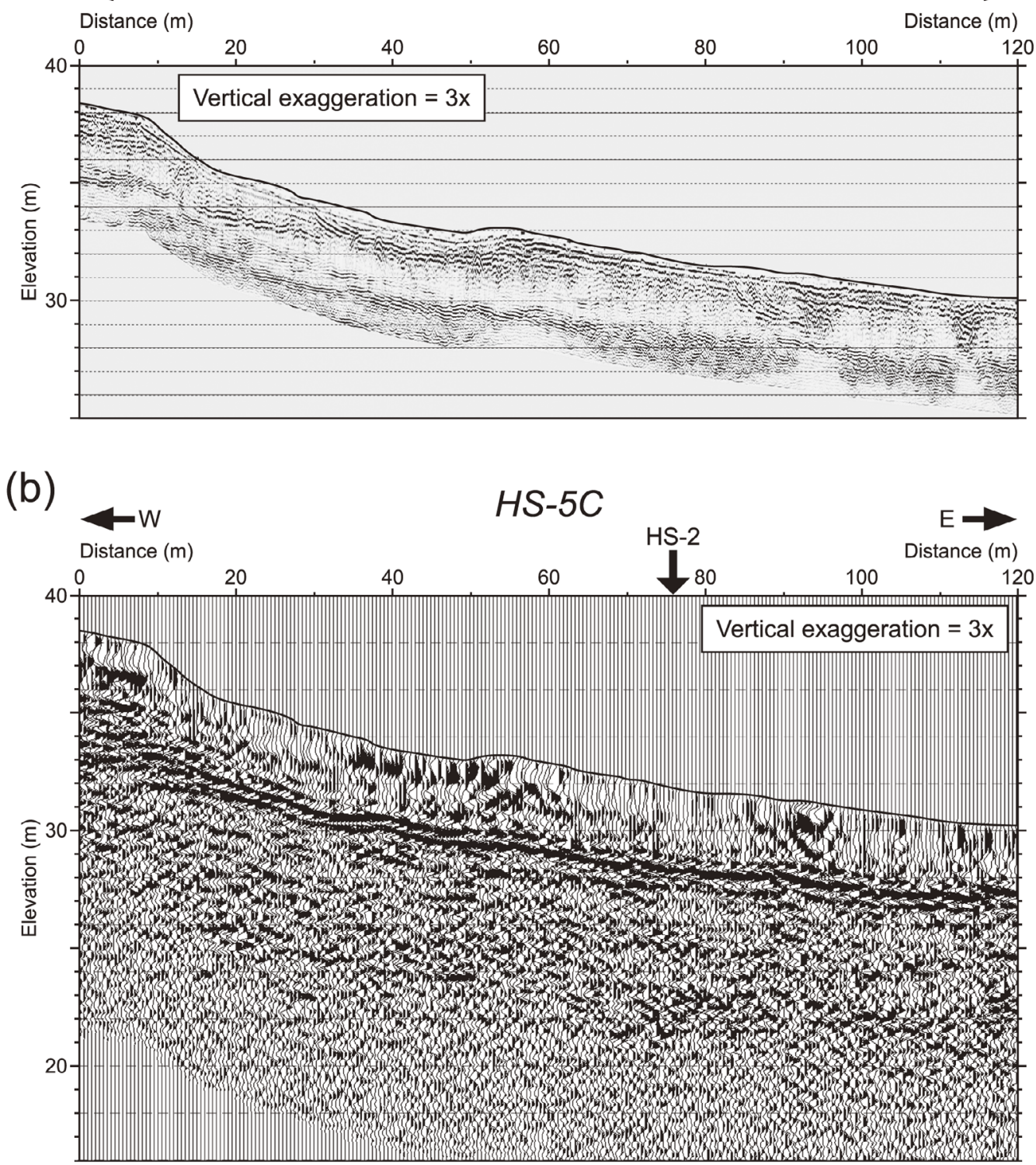

図 8

Fig. 8 
(c)
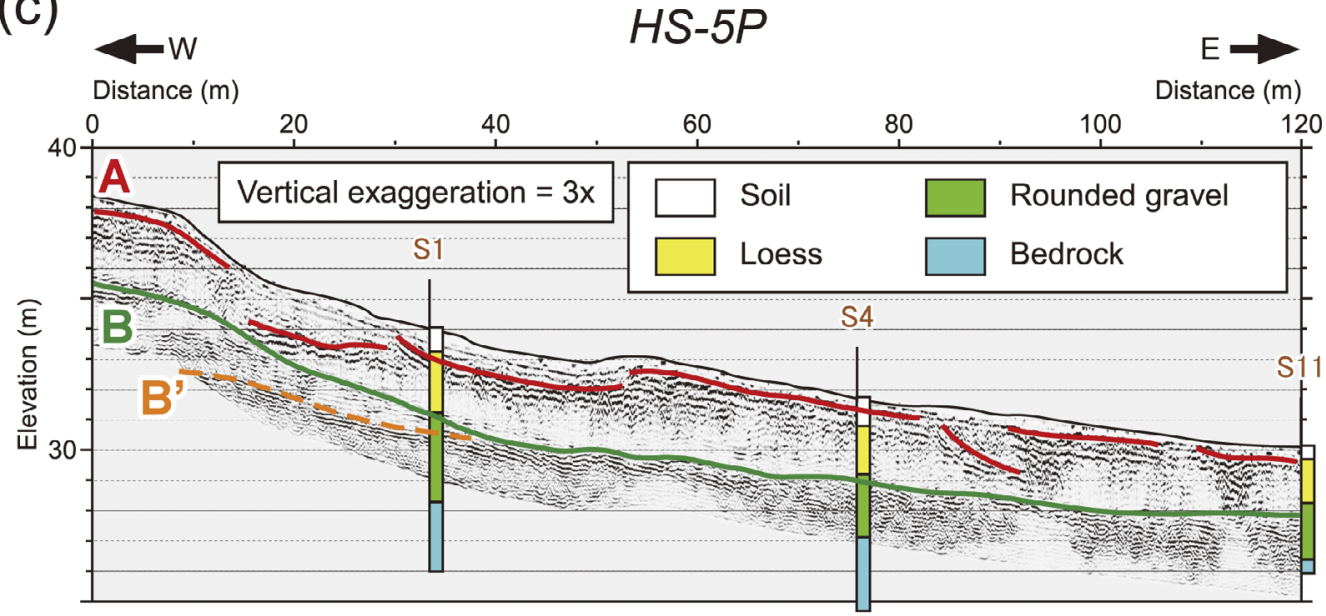

(d)

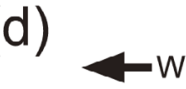

HS-5C

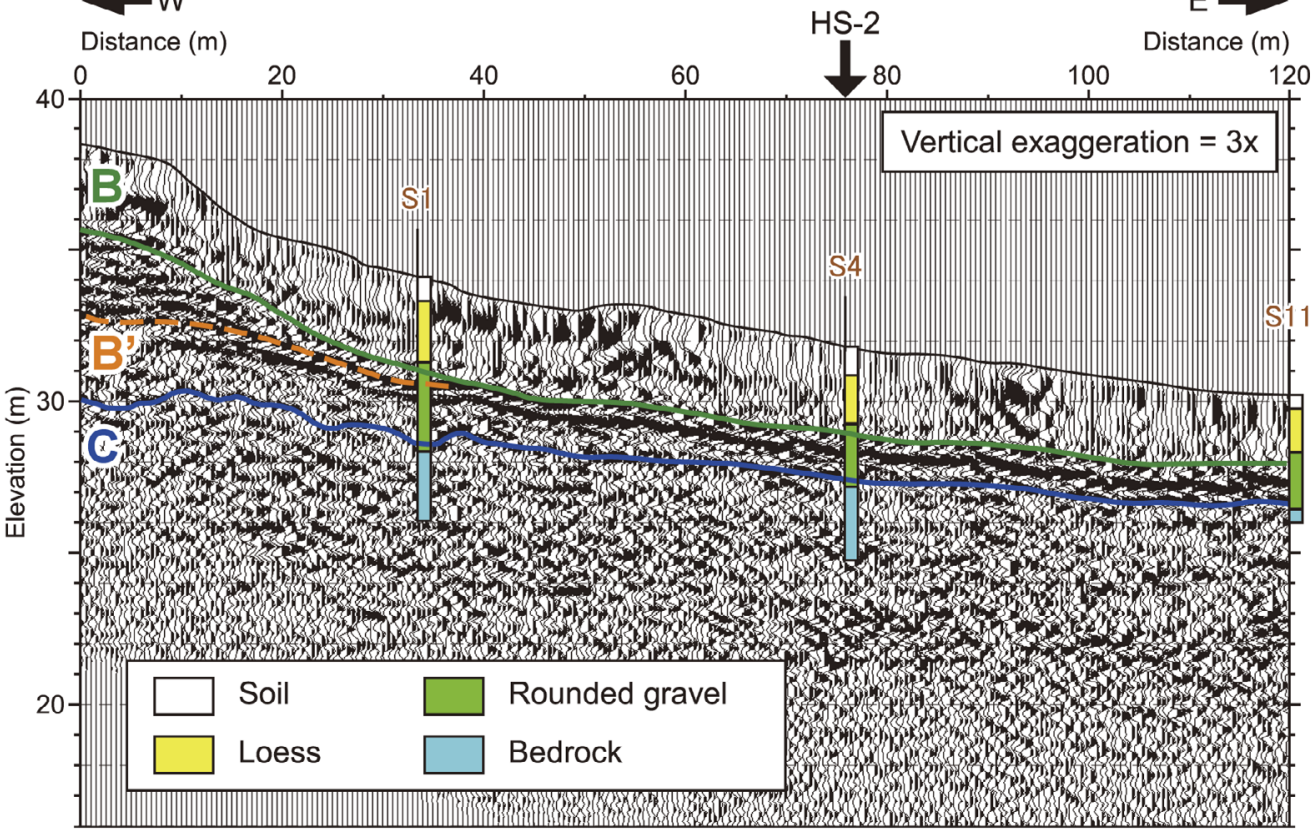

図 8 HS-5 測線の地中レーダー探査断面. 深度方向に 3 倍強調. 図中のボーリング柱状図は Matsu'ura et al. （2014）に基づく.（a）インパルス地中レーダー探査の深度変換断面.（b）ステップ式連続波地中レー ダー探査の深度変換断面.（c）インパルス地中レーダー探査の解釈断面. (d) ステップ式連続波地中レーダー 探査の解釈断面.

Fig. 8 GPR sections of line HS-5. The vertical exaggerations in all sections are three times. Geologic columns of drillcores are based on Matsu'ura (2014). (a) Depth-converted section of impulse GPR profiling. (b) Depth-converted sections of stepped frequency modulated continuous wave GPR profiling. (c) Geologic interpretation of impulse GPR section 8a. (d) Geologic interpretation of stepped frequency modulated continuous wave GPR section 8b. 
(a)

Distance $(m)$

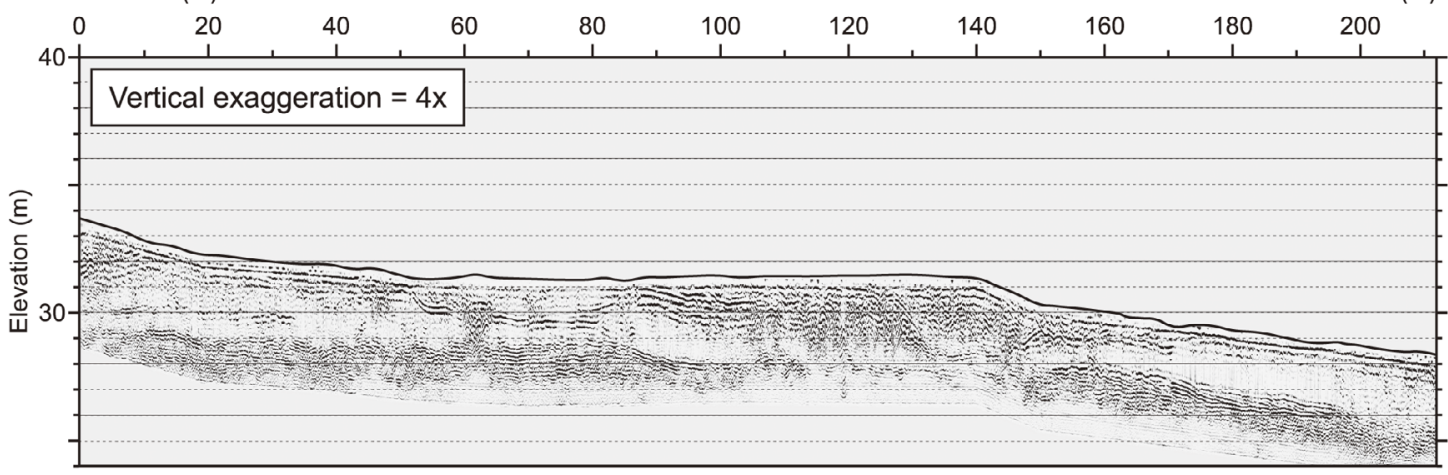

(b)

HS-2C

N

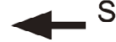

Distance $(\mathrm{m})$

Distance (m)

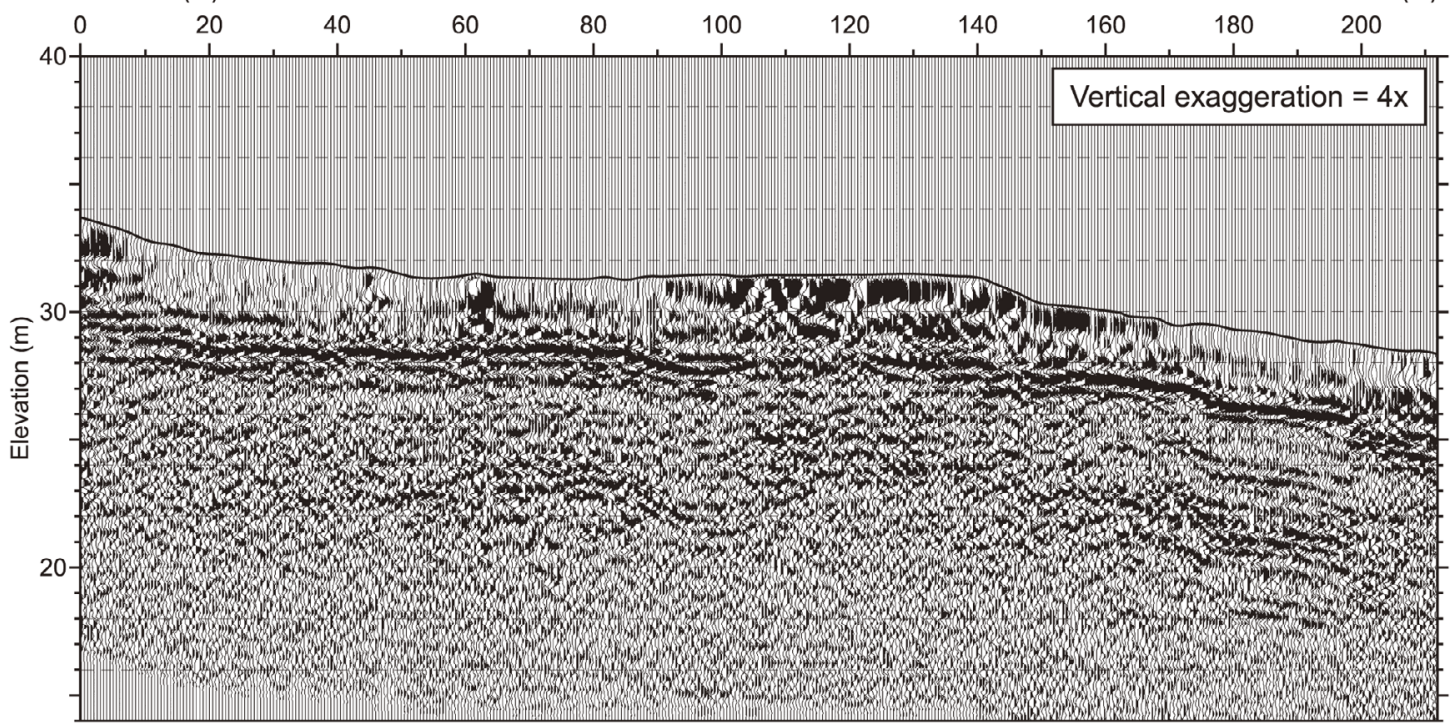

図 9 .

Fig. 9. 
(c)

Distance $(m)$

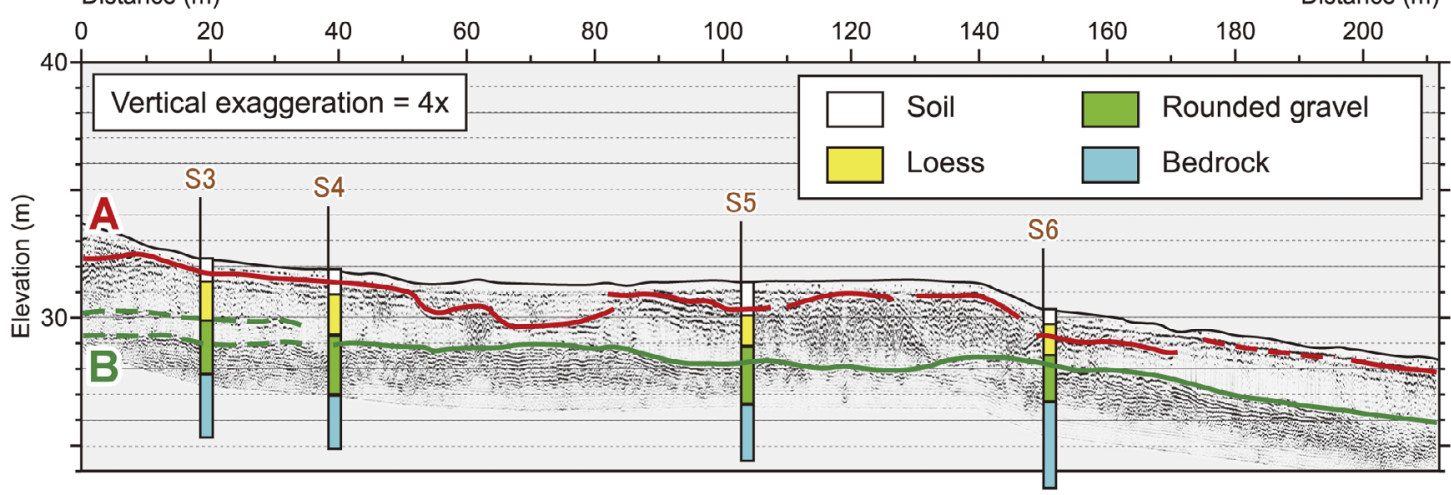

(d)
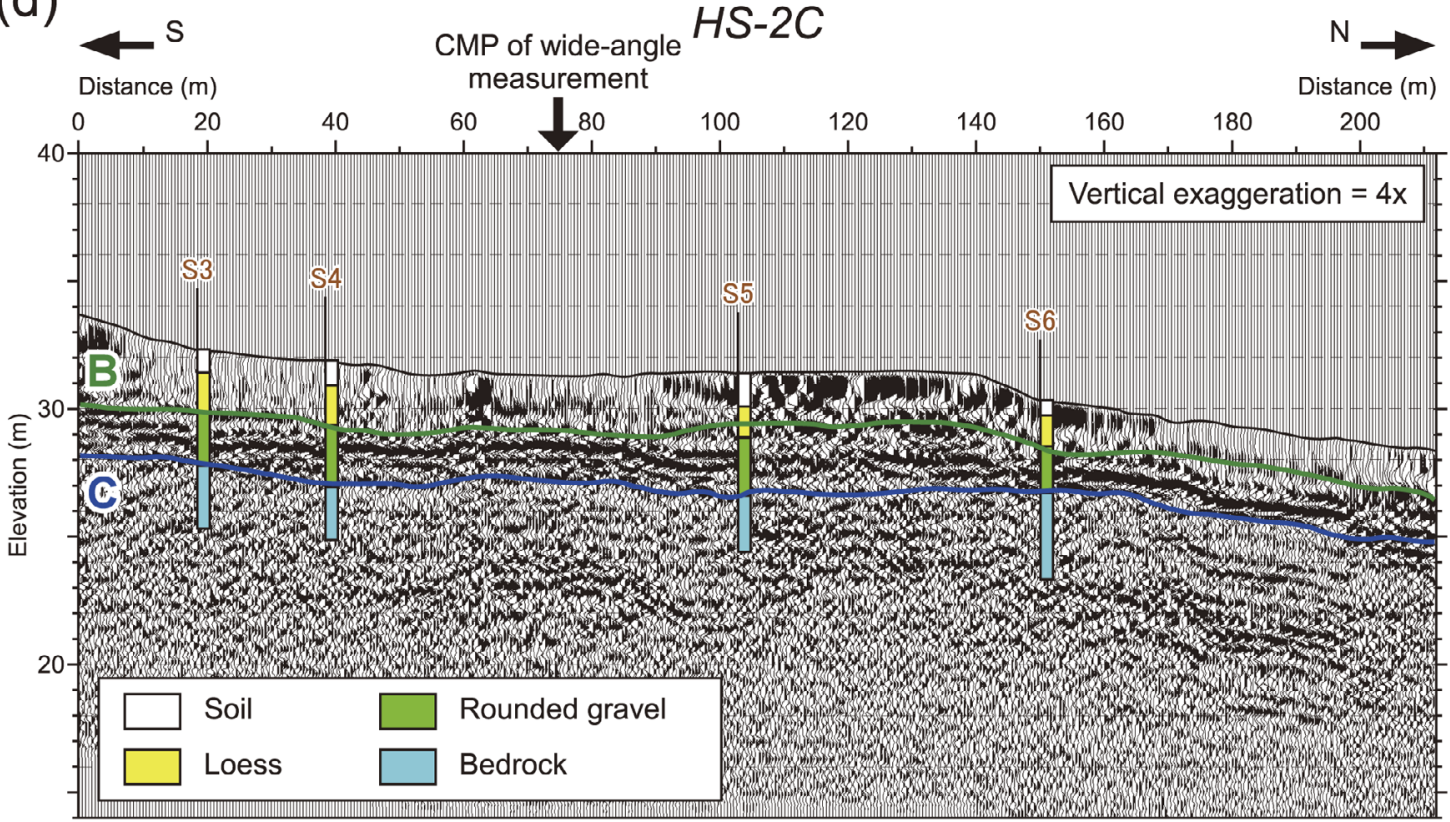

図 9 HS-2 測線の地中レーダー探査断面. 深度方向に 4 倍強調. 図中のボーリング柱状図は Matsu'ura et al.（2014）に基づく.（a）インパルス地中レーダー探査の深度変換断面.（b）ステップ式連続波地中レー ダー探査の深度変換断面. (c)インパルス地中レーダー探査の解釈断面. (d) ステップ式連続波地中レーダー 探査の解釈断面.

Fig. 9 GPR sections of line HS-2. The vertical exaggerations in all sections are four times. Geologic columns of drillcores are based on Matsu'ura (2014). (a) Depth-converted section of impulse GPR profiling. (b) Depth-converted sections of stepped frequency modulated continuous wave GPR profiling. (c) Geologic interpretation of impulse GPR section 9a. (d) Geologic interpretation of stepped frequency modulated continuous wave GPR section $9 \mathrm{~b}$. 
測線位置は図 4 参照）についても述べる。なお, これらの断面の解釈にあたって参考としたボーリ ング柱状図を，図 8c，d および図 $9 \mathrm{c} ， \mathrm{~d}$ の地中 レーダー探査断面に重ねて表示した。

\section{1）インパルス地中レーダー探査 HS-5P 測線}

東西方向の HS-5P 測線の深度変換断面図を図 $8 \mathrm{a}$ に，その地質学的解釈を図 $8 \mathrm{c}$ に示す。インパ ルス地中レーダー探査データについてはすべての 測線で地表下約 $5 \mathrm{~m}$ の深度までデー夕処理を行 い, 深度変換断面を作成した。

断面の特徴を断面上端から順に述べる。浅いと ころで地表下深度 $0.5 \mathrm{~m}$ 程度, 深いところで地表 下深度 $1.5 \mathrm{~m}$ 程度の所に数列の連続性のよい波列 群が認められる。これらの波列群は，ほぼ平行な 数列の波列で構成されている。最上位に位置する 波列（図 8c の赤色線）が真の反射面だと考えら れ，その下位に位置する波列群は，除去しきれ ていないリンギングノイズという可能性が高い。 地表下深度数 $\mathrm{m}$ までの範囲では, これらの反射 面の上方および下方ともに，連続性のよい明瞭な 反射面はみられない。一般的に, 内部構造として 明瞭な電磁気的物性コントラストをもたない土 壤・レス層内部では強い反射は期待できないこと から，この反射面（図 8c の赤色線）の上位の領 域は土壤層, 下位の領域はレス層と判断し, 図 $8 \mathrm{c}$ の赤色線をそれらの境界面（A 面）とした。

地表下深度数 $\mathrm{m} \sim$ 断面下端までの領域では数 多くの波列で特徴づけられる。これらはお互いに 平行な数列の波列群だけではないことから, リン ギングノイズではない真の反射面も数多く存在し ていると判断できる。調査地域の地下浅部に存在 する地層では, 砂磁層の場合にはその堆積構造に よってこうした数多く反射面がみられるはずで ある。このことから，この深度領域は礫層に相当 するものと判断した。また，こういった特徵のみ られる領域の上限（図 8c の緑色線）をレス層と 礫層の境界面（B 面）とした。ただし, 距離 $0 \mathrm{~m}$ 地点〜 $38 \mathrm{~m}$ 地点では， $\mathrm{B}$ 面よりも下方にも特徵 的な反射面がみられ，この反射面も距離 $40 \mathrm{~m}$ 地 点〜 $120 \mathrm{~m}$ 地点での $\mathrm{B}$ 面と似た特徵をもってい ることから， B'面とした。B' 面については距離
$0 \mathrm{~m}$ 地点〜 $38 \mathrm{~m}$ 地点の $\mathrm{B}$ 面との間に挟まれる ウェッジ状の領域の反射面の特徵（とくに, 後述 する図 8d の断面で顕著）も，距離 $40 \mathrm{~m}$ 地点〜 $120 \mathrm{~m}$ 地点の $\mathrm{B}$ 面下方の礫層とよく似ているこ とから, 距離 $0 \mathrm{~m}$ 地点〜 $38 \mathrm{~m}$ 地点においても, 礫層の上面は B' 面ではなく $\mathrm{B}$ 面と考えられる。

HS-5P 断面で解釈された土潩とレス層の境界 面（A 面）は，ほとんどの区間では地表下深度 $0.5 \sim 1.0 \mathrm{~m}$ 前後で，その断面形状は地表面とほ ぼ並行である。しかし，一部の区間（距離 $15 \mathrm{~m}$ 地点 $28 \mathrm{~m}$ 地点, 距離 $86 \mathrm{~m}$ 地点 $\sim 91 \mathrm{~m}$ 地点) では他の区間に比べて深い。距離 $15 \mathrm{~m}$ 地点〜 $28 \mathrm{~m}$ 地点のものについては，ちょうどこの近辺の 微地形は緩やかな小谷状になっており，その影響 が疑われる。同じく HS-5P 断面で解秎されたレ 又層と礫層の境界面（B面）は，地表面とほほ同 じ傾斜で，東側（海側）へ向かって標高を減じる。

2）ステップ式連続波地中レーダー探査 HS-5C 測線

東西方向の HS-5C 測線の深度変換断面図を図 $8 \mathrm{~b}$ に，その地質学的解釈を図 $8 \mathrm{~d}$ に示す。ステッ プ式連続波地中レーダー探査データについてはす べての測線で地表下深度約 $17 \mathrm{~m}$ までデー夕処理 を行ったが，地表下深度 $10 \mathrm{~m}$ 以深では明瞭な反 射面はみられなかったので，本稿で示した深度変 換断面の一部では深部の領域を割愛した（図 $8 \mathrm{~b}$ では距離 $40 \mathrm{~m}$ 地点〜 $120 \mathrm{~m}$ 地点の区間では深 い部分を切り取っている)。

以下では，断面の特徵を断面上端から順に述べ る。地表から地表下深度数 $\mathrm{m}$ までの領域では波 形トレースが上下に間延びしているようにみえ る。これは, 今回のステップ式連続波地中レー ダー探査では，送信アンテナー受信アンテナ間隔 が $3 \mathrm{~m}$ と大きく離れており，その影響を NMO 補 正処理によって取り除いたため，表層部で波形卜 レースが間延びしたものである。よって地表から 地表下深度数 $\mathrm{m}$ までの領域は分解能が低く, イン パルス地中レーダー探査（図 8c）のような $\mathrm{A}$ 面に 相当する反射面は一部（距離 $20 \mathrm{~m}$ 地点〜 $30 \mathrm{~m}$ 地点, 距離 $35 \mathrm{~m}$ 地点 $55 \mathrm{~m}$ 地点, 距離 $85 \mathrm{~m}$ 地点〜90 $\mathrm{m}$ 地点）を除いて認識が困難である。 
地表下深度 $2 \mathrm{~m}$ ないし $3 \mathrm{~m}$ より下方では, 3 〜 4 枚あるいはそれ以上の連続性のよい反射面群が みられる。このような明瞭な反射は砂層の上面・ 下面および礫層内部の地層面から返ってきている ものと考え，こうした反射面群で特徴づけられる 領域は礫層に相当すると判断した。また，これら の明瞭で連続性のよい反射面群の最も上位のもの をレス層と礫層の境界面 (B 面), 最も下位のも のを礫層と基盤岩の境界面（C 面）とした。また, 本断面でも HS-5P 断面と同様に距離 $0 \mathrm{~m}$ 地点 $38 \mathrm{~m}$ 地点の特徵的な反射面を B' 面とした。な お, 断面西部（距離 $0 \mathrm{~m}$ 地点〜 $30 \mathrm{~m}$ 地点）では C 面の連続性がやや不明瞭である。

上記の強い反射がみられる領域よりもさらに深 い部分では，反射面の連続性が非常に悪くなり， 構造は不明瞭である。この領域は基盤岩に相当す るものと判断した。

HS-5C 断面で解釈されたレス層と磁層の境界 面（B 面）は，インパルス地中レーダー探査断面 （図 8c）のB 面と同様に，地表面とほほ同じ傾斜 で，東側（海側）へ向かって標高を減じる。また, 礫層と基盤岩の境界面（C 面）も海側へ緩やかに 傾斜するが，その傾斜は B 面に比べるとかなり 小さい。

3）インパルス地中レーダー探査 HS-2P 測線

南北方向の HS-2P 測線の深度変換断面図を図 $9 \mathrm{a}$ に，その地質学的解釈を図 $9 \mathrm{c}$ に示す。探査断 面の特徵や, 地質学的解釈の基準 - 根拠について は, HS-5P 測線のものと同様である。ただし, 一部の区間で $\mathrm{A}$ 面あるいは B 面が不明瞭であっ たため, それらについては図 9c 中において破線 で示した。とくにB面については, 断面南端付近 （距離 $0 \mathrm{~m}$ 地点〜 $35 \mathrm{~m}$ 地点）では, 標高 $30 \mathrm{~m}$ 前後にやや不明瞭ながらも連続性のよい反射面が 認められるが，これより北方の区間（距離 $40 \mathrm{~m}$ 地点〜) からの連続性・断面の特徵を考慮すると, 標高 $29 \mathrm{~m}$ 前後に認められる面構造の方が $\mathrm{B}$ 面に 相当するとも考えられる。一方で，HS-2P 測線の 距離 $19 \mathrm{~m}$ 地点付近で掘削された $\mathrm{S} 3$ ボーリング の結果（図 9c) では，B面の標高は $30 \mathrm{~m}$ となっ ている。そこで図 9c の断面では標高 $29 \mathrm{~m}$ の面
と標高 $30 \mathrm{~m}$ の面の両方を破線で併記した。

HS-2P 断面で解釈された土壤とレス層の境界 面（A 面）も，HS-5P 断面に打ける A 面と同様に, ほとんどの区間では地表下深度 $0.5 \sim 1.0 \mathrm{~m}$ 前後 で，その断面形状は地表面とほぼ並行である。た だし，距離 $68 \mathrm{~m}$ 地点〜 $78 \mathrm{~m}$ 地点の区間は他に 比べて深くなっている。これも HS-5P と同じく, 距離 $68 \mathrm{~m}$ 地点〜 $78 \mathrm{~m}$ 地点の区間に存在する緩 やかな小谷状の微地形の影響が疑われる。また, HS-2P 断面で解釈されたレス層と礫層の境界面 （B 面）は，地表面の断面形状とほぼ同じ形状を 示し, 断面南部・中部（距離 $0 \mathrm{~m}$ 地点 $150 \mathrm{~m}$ 地点）ではほぼ水平で, 断面北部（距離 $150 \mathrm{~m}$ 地点〜断面北端）では緩やかに北傾斜する。

\section{4）ステップ式連続波地中レーダー探査 HS-2C 測線}

南北方向の HS-2C 測線の深度変換断面図を図 $9 \mathrm{~b}$ に，その地質学的解釈を図 $9 \mathrm{~d}$ に示す。探査断 面の特徵や，地質学的解釈の基準・根拠について は, HS-5C 測線のものと同様である。

HS-2C 測線の距離 $75 \mathrm{~m}$ 地点では, ワイドア ングル測定とその測定データについての速度解析 が行われたので，ここでは HS-2C 断面を参照し て速度解析結果との関係について述べる。ワイド アングル測定データ（図 6）では，読み取り速度 （図 6b）に対応する特徵的な反射波列 $\mathrm{R} 1 \sim \mathrm{R} 4$ （図 6a）が認められ，これらの反射に対応する梁 度は地表下 $2.40 〜 4.81 \mathrm{~m}$ となる。ワイドアング ル測定を行った地点に対応する，HS-2C 断面の 距離 $75 \mathrm{~m}$ 地点では，標高およそ $29 \sim 27 \mathrm{~m}$ の 範囲に明瞭な 4 枚の反射面が認められる。 HS-2C 測線の測量結果によれば，この距離 $75 \mathrm{~m}$ 地点 （ワイドアングル測定を行った地点）での地表面標 高は $31.2 \mathrm{~m}$ であるので，標高およそ $29 \sim 27 \mathrm{~m}$ の範囲は深度に換算すると地表下およそ 2.2 〜 $4.2 \mathrm{~m}$ となる。したがって，ワイドアングル測定 でみられた反射の深度と, HS-2 測線プロファイ ル測定でみられた反射面の深度は，やや異なって いる。しかし, 該当地点・深度領域での本探査に おける鉛直分解能は $0.2 \sim 0.3 \mathrm{~m}$ 前後であり，プ ロファイル測定（HS-2C 測線）とワイドアング 
ル測定双方の鉛直分解能と測定誤差を考慮する と，ややずれが大きいものの，両者でみられた反 射は対応しているものと考えられる。

このような 4 枚あるいは 5 枚の明膫な反射面 で特徴づけられる領域は HS-2C 断面全域にわ たって認められ，反射断面の特徵およびボーリン グデータとの対応関係からも，この領域は碟層に 相当するものと判断される。距離 $75 \mathrm{~m}$ 地点でみ られた深度方向への構造は, この地点だけの特異 な構造というわけではなく，断面全体を代表する 平均的な構造といってよい。そのため, HS- $2 \mathrm{C}$ 測線およびその周辺の他の測線における平均的な 多層地中電磁波速度構造モデルとして, HS- $2 \mathrm{C}$ 測線の距離 $75 \mathrm{~m}$ 地点で行った速度解析結果を用 いても，大局的には差し支えないといえる。ただ しもちろん，ボーリングデータが分布していない 場所では上記の対応関係を確認できていないわけ であり，ボーリング掘削地点間には局所的に地中 電磁波速度が変化している領域が存在する可能性 もある。したがって，そのような局所的な範囲の 地下構造を解釈する際には注意が必要である。

$\mathrm{HS}-2 \mathrm{C}$ 断面で解釈されたレス層と砂層の境界 面 (B 面) は，インパルス地中レーダー探査断面 （図 9c）のB 面と同様に，地表面の断面形状とほ ほ同じ形状を示し, 断面南部・中部（距離 $0 \mathrm{~m}$ 地点〜 $150 \mathrm{~m}$ 地点）ではほぼ水平で，断面北部 （距離 $150 \mathrm{~m}$ 地点〜断面北端）では緩やかに北傾 斜する。ただし，インパルス地中レーダー探査断 面では距離 $0 \mathrm{~m}$ 地点〜 $35 \mathrm{~m}$ 地点の区間では $\mathrm{B}$ 面が不明暸であったのに対し，ステップ式連続波 地中レーダー探査断面では標高 $30 \mathrm{~m}$ 前後に明瞭 な反射面が認められたため，この区間に存在する S3 ボーリングデータからも, 標高 $30 \mathrm{~m}$ 前後の面 が B 面に相当すると判断した。また，礫層と基盤 岩の境界面 (C 面) については, B 面よりも数 $\mathrm{m}$ 下方に位置するが，その断面形状は B 面とほぼ 同様である。

\section{V. 考 察}

\section{1）調査範囲北西部の不均質構造}

本調査範囲の地下浅部構造の特徵は, 前述した
HS-2P，HS-2C，HS-5P，HS-5C といった代表 的な測線群によって説明できるが，調査範囲の北 西部において，他とは異なる構造が認められた。 この特異な構造は HS-1 測線（図 4）においてのみ 認められたため，HS-1P 断面および HS-1C 断面 （図 10）を図示して，その構造について述べる。

HS-1P 断面も HS-2P 断面・ HS-5P 断面と同 様の判断・解勫基準によって地質学的解釈を行っ た（図 10c）。A 面は断面北部の一部区間（距離 $155 \mathrm{~m}$ 地点〜 $160 \mathrm{~m}$ 地点周辺) や断面南端部を 除く，断面のほぼ全域で認められた。ただし，A 面の構造に関してはここではとくにとりあげな い。B 面は断面内の所々で連続性が悪くなって おり，断続的な追跡となった。しかし，B面を 解釈できた区間においては，ボーリング掘削結 果や後述する HS-1C 断面とはよく対応している。 HS-1P 断面内での B 面の構造をみると，断面北 部の距離 $115 \mathrm{~m}$ 地点〜断面北端でとくに, 多く の不連続や大きな深度変化がみられる。

HS-1C 断面についても HS-2C 断面・HS-5C 断面と同様の判断・解釈基準によって地質学的解 釈を行った（図 10d）。HS-1C 断面の北部（距離 $115 \mathrm{~m}$ 地点〜断面北端）では，強い反射が多く みられるものの, 複雑な構造を呈しており，ま た，一部では反射面の連続性が悪く乱れている領 域もある。距離 $115 \mathrm{~m}$ 地点〜断面北端の区間で は， B 面の解釈においてはインパルス地中レー ダー探査の結果も参考にすることにより，ホライ ゾンを追跡することができたが，C 面については 区間全域にわたって追跡することができなかっ た。距離 $166 \mathrm{~m}$ 〜断面北端については HS-1 測線 と交差する HS-7 測線や HS-9 測線（図 4）での 解釈ホライゾンとの接続関係から, 標高 $26.5 \mathrm{~m}$ 前後のやや平坦な反射面を C 面と判断した。し かし，距離 115～165 mの区間では，他のステッ プ式連続波地中レーダー探査断面での C 面の解 釈と同様に強い反射面群の最下位のものを追跡し たが，反射面の途切れや大きな起伏のために，明 瞭な連続性をもった面構造として追跡することは できなかった。そこで，この区間については推定 的なホライゾンとして，図 $10 \mathrm{~d}$ 中に水色破線の 
C'面というように示した。

また，HS-1C 断面北部では，C 面（および C' 面）のさらに下位に凹状の断面形状を呈する反射 面（図 10d 中の桃色破線の C”面）がみられる。 HS-1 測線の距離 $165 \mathrm{~m}$ 地点付近で掘削された $\mathrm{S} 2$ ボーリング（図 10b）の結果からは，C”面の 深度の方が C 面（および C'面）深度と比べて, 礫層と基盤岩の境界面深度により整合的である。 しかし, 本探査での他のステップ式連続波地中 レーダー探査断面ではほぼ一様に, 数 $\mathrm{m}$ 程度の 厚さをもって分布する明瞭な反射面群の最下位の ものが，礫層と基盤岩の境界面に相当していた。 そうした反射断面の特徵から考えると, HS-1C 断面では C”面ではなく，C面（および C'面）が 礫層と基盤岩の境界面といえる。さらに，C”面 と接続関係を有する明瞭で連続性のよい反射面 が，HS-1 測線と交差する HS-7 測線や HS-9 測 線ではみられなかったこともあり, 地中レーダー 探査から推定される礫層と基盤岩の境界面は $\mathrm{C}$ 面（および C’面）として，以下の考察を進める。

HS-1P 断面および HS-1C 断面では, 距離 $115 \mathrm{~m}$ 地点〜 $170 \mathrm{~m}$ 地点の範囲で反射面の起伏・乱れ が目立つ。とくにHS-1C 断面では, 距離 $120 \mathrm{~m}$ 地点付近, 距離 $145 \mathrm{~m}$ 地点付近, 距離 $165 \mathrm{~m}$ 地 点付近では反射面が凹状の形状を呈する。これら の地点では $\mathrm{B}$ 面や $\mathrm{C}^{\prime}$ 面として解釈された反射面 も凹状になっている。 B 面や C 面 (C'面) に相 当する反射面のこうした顕著な凹状形態は，本探 査の他の断面ではみられず, HS-1 測線の距離 $115 \mathrm{~m}$ 地点〜 $170 \mathrm{~m}$ 地点のみでみられる非常に 局所的な現象だと考えられる。このような探査断 面の特徴が何に起因するものかと考えると, 反射 面の形状にそのまま対応する凹状の地質構造が存 在するという可能性のほかに，地質構造には起伏 はなくとも比較的狭い領域で高含水率の地層が存 在しているという可能性がある。局所的な凹状反 射面の原因を明らかにするためには，この範囲 (HS-1 測線の距離 $115 \mathrm{~m}$ 地点〜 $170 \mathrm{~m}$ 地点) で, 多くの共通反射点においてワイドアングル測定を 行い, より詳細な地中電磁波速度構造を求めるこ とが必要である。しかし本研究の目的は，鉛直地
殼変動量を求める指標のひとつとして, 埋没地形 の形状・高度情報を解明することであるので, HS-1 測線の一部でみられたような非常に局所的

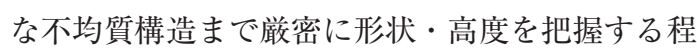
の必要はない。ただし，形状的あるいは含水率的 のいずれにしろ，この範囲には不均質な構造が存 在していることは事実なので，後述する本調査地 域全体における海成段丘の地下浅部構造の考察に おいては, HS-1 測線の距離 $115 \mathrm{~m}$ 地点〜 $170 \mathrm{~m}$ 地点の区間の特異性には注意を払って議論を行 う。

\section{2) 本探査範囲における海成段丘の地下浅部構造}

インパルス地中レーダー探査 HS-1P HS-9P 断面に拈ける $\mathrm{B}$ 面 (レス層と礫層の境界面), ステップ式連続波地中レーダー探査 HS-1C HS-9C 断面における B 面と C 面（礫層と基盤岩 の境界面）から， 3 次元的な面形状を推定し，本 探査地域の地下浅部構造について考えた。ここ で，B面については，インパルス地中レーダー探 査断面とステップ式連続波地中レーダー探査断面 のほとんどの範囲で位置・形状ともにほぼ一致し ていた。しかし，両者が異なる場合は，高周波型 でより分解能の高いインパルス地中レーダー探査 の結果を重視しつつも，それぞれの断面での明瞭 さやボーリング掘削結果との整合性から，より信 頼性が高いものを採用した。このようにして推定 した地下浅部構造と地表地形について, 図 $11 に$ まとめた。地表地形の等高線図については, 地中 レーダー探査測線に沿った測量結果に基づくもの と, 航空 LIDARによる $2 \mathrm{~m}$ メッシュ標高データ に基づくものの両方を作成した。測線測量デー夕 による地表面, B面 (レス層と礫層の境界面), $\mathrm{C}$ 面（礫層と基盤岩の境界面）の形状， LIDAR デー夕による地表面を図 $11 \mathrm{a} \sim \mathrm{d}$ に, 土壤・レ

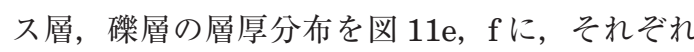
示す。なお， 3 次元的な面形状の作成にあたって は，LIDARによる標高データのメッシュ間隔に あわせて, 補間間隔を $2 \mathrm{~m}$ として補間計算を行っ てグリッドデータを作成した。

まず，測線測量データから作成した地表面（図 11a）と LIDAR データから作成した地表面（図 
(a)

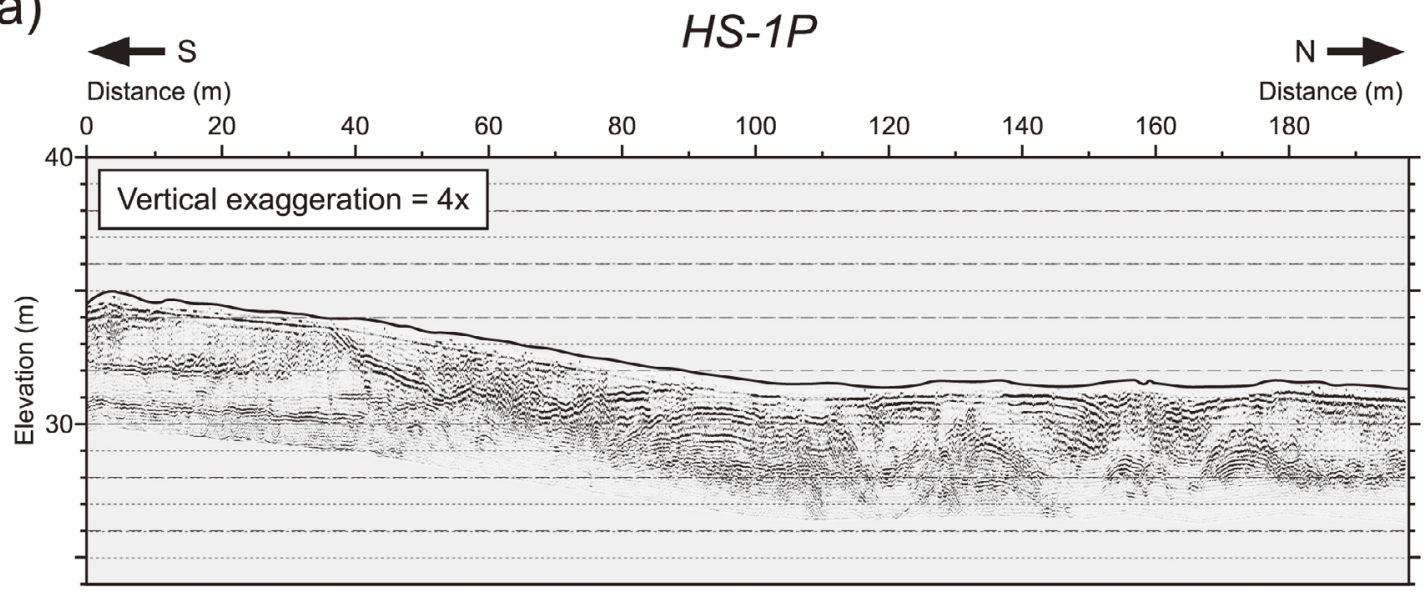

(b)

HS-1C

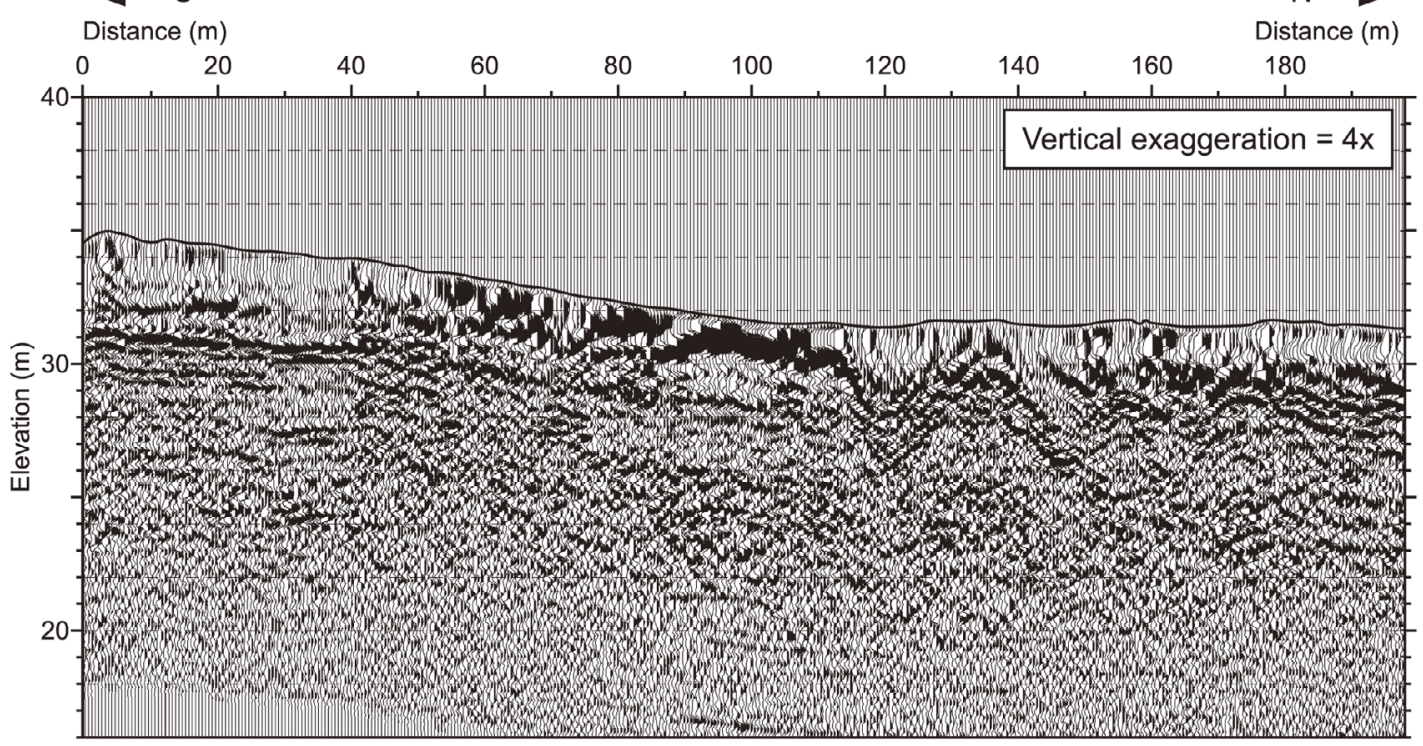

図 10 .

Fig. 10 . 
(c)

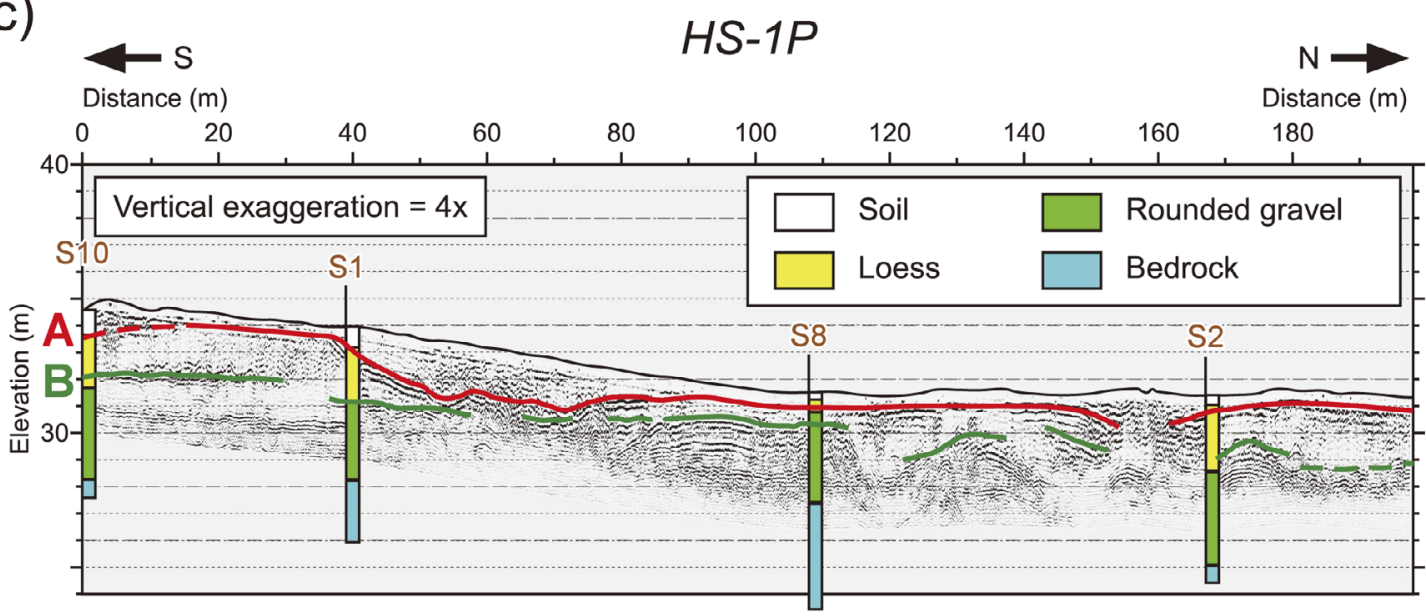

(d)

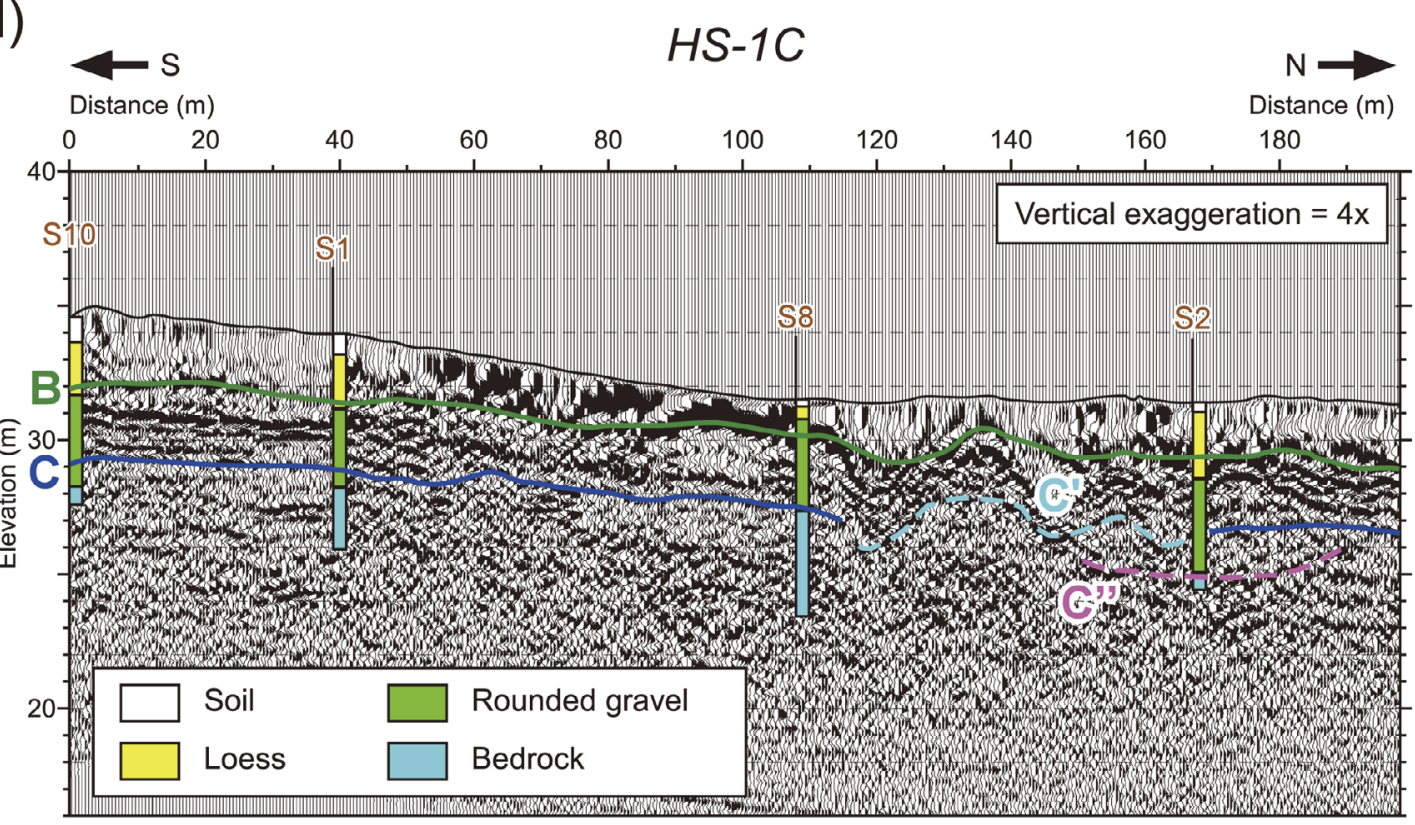

図 10 HS-1 測線の地中レーダー探査断面. 深度方向に 4 倍強調. 図中のボーリング柱状図はMatsu'ura et al.（2014）に基づく.（a）インパルス地中レーダー探査の深度変換断面.（b）ステップ式連続波地中レー ダー探査の深度変換断面.（c）インパルス地中レーダー探査の解橎断面.（d）ステップ式連続波地中レー ダー探査の解橎断面.

Fig. 10 GPR sections of line HS-1. The vertical exaggerations in all sections are four times. Geologic columns of drillcores are based on Matsu'ura (2014). (a) Depth-converted section of impulse GPR profiling. (b) Depthconverted sections of stepped frequency modulated continuous wave GPR profiling. (c) Geologic interpretation of impulse GPR section 10a. (d) Geologic interpretation of stepped frequency modulated continuous wave GPR section $10 \mathrm{~b}$. 
(a)

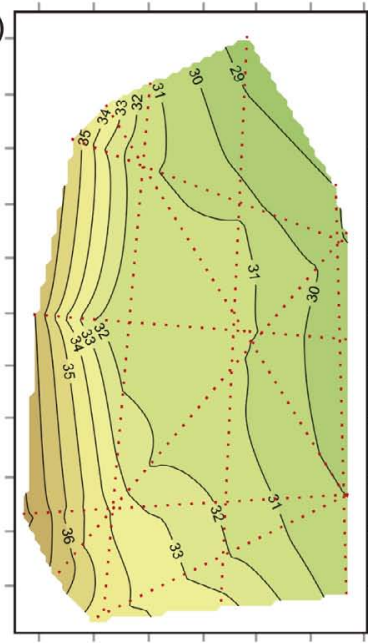

(b)

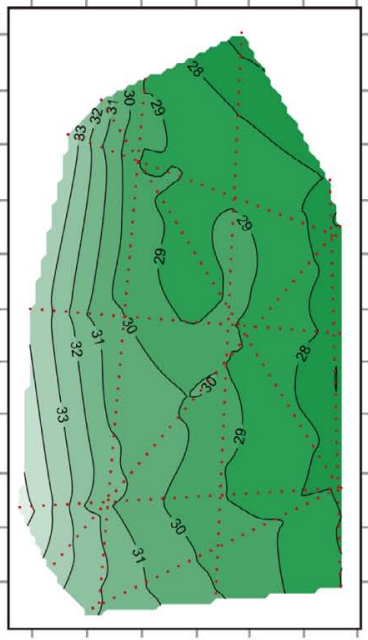

(d)

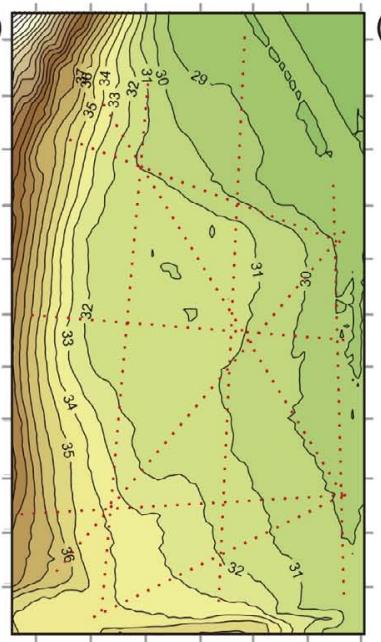

(e)

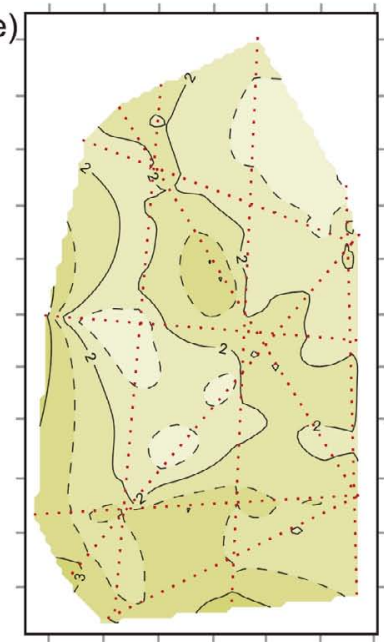

$(f)$

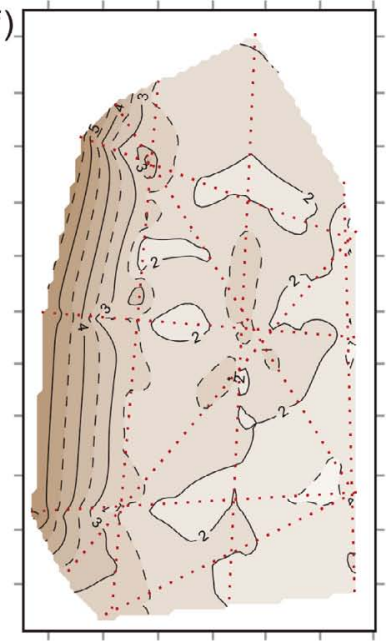

(c)
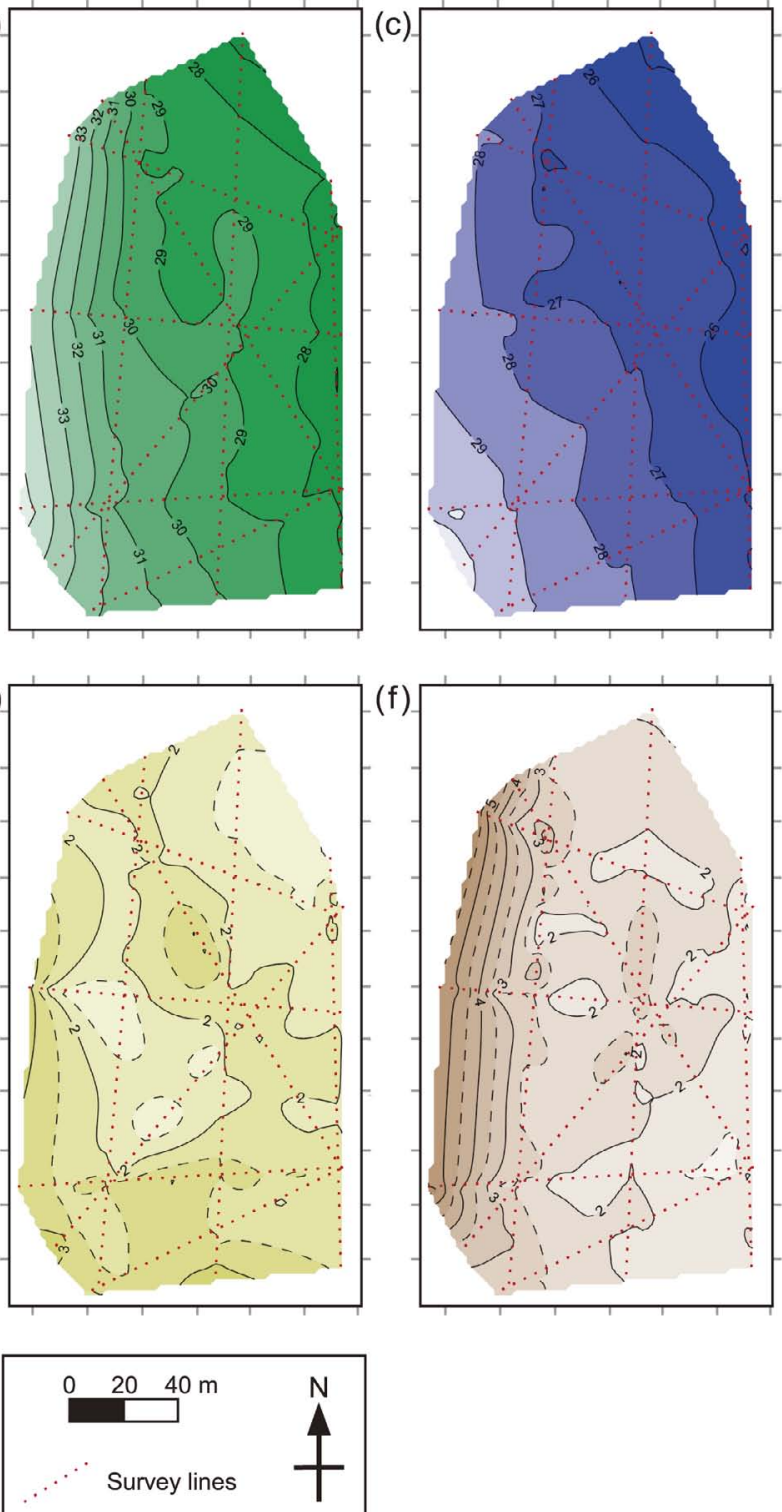

図 11 本研究の地中レーダー探查によって得られた浅部地下構造. 図（a，b，c，d）中の等高線間隔はそれぞ

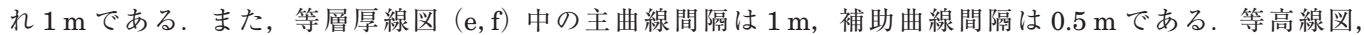
等層厚線図中の值はそれぞれ，標高，層厚を示す。（a)GPR 探査測線沿いの測量結果から作成した地形図. (b) B 面の等高線図。(c) C 面の等高線図。(d) $2 \mathrm{~m}$ メッシュ航空 LIDAR デー夕から作成した地形図。（e) 土壤掞よびレス（地表面と $\mathrm{B}$ 面の間の層）の等層厚線図。(f) 磁層（B面と $\mathrm{C}$ 面の間の層）の等層厚線図.

Fig. 11 Shallow subsurface structure inferred from GPR profiling in study. Contour intervals are $1 \mathrm{~m}$ in maps $(\mathrm{a}, \mathrm{b}$, $\mathrm{c}$, and d). In maps (e and f), solid-contour intervals are $1 \mathrm{~m}$; broken-contour intervals are $0.5 \mathrm{~m}$. The values in contour maps (a, b, c, and d) and isopach maps (e and f) are elevations and thicknesses, respectively. (a) Contour map of ground surface based on topographic profiles along GPR survey lines. (b) Contour map of horizon B. (c) Contour map of horizon C. (d) Contour map of ground surface based on 2-m mesh digital elevation model obtained with airborne LIDAR system. (e) Isopach map of soil and loess between ground surface (a) and horizon B (b). (f) Isopach map of rounded gravel bed between horizon B (b) and horizon C (c). 
11d）を比較すると，大局的にはほぼ同様である ことがわかる。さらに詳細に比較すると, 調查範 囲の南西部および北西部でみられる小規模な谷地 形が，LIDARに基づく地表面（図 11d）と同じ く, 測線沿いデー夕に基づく地表面（図 11a）で も表現されていることがわかる。したがって，本 探査範囲における 3 次元的な面形状作成では, 今 回の探査の際の測線配置と, 面形状計算の際の補 間間隔によって, 本研究の目的にかなった議論に 足りる程度には正確な面形状が作成されたと考え てよい。ただしその一方で，1 か所だけではある が，測線沿いデー夕に基づく地表面（図 11a）で は, HS-6 測線西部（範囲内の中央西部）に実際 の地表地形では存在しない谷地形が現れてしまっ ているので, 3 次元形状の議論ではこの場所につ いては注意が必要である。

図 11 上段の 3 つの面形状をみると,すべて大 局的には東側 (海側) へ向かって傾斜している。 このうちとくに，地表面（図 11a）と磁層上面で ある B 面（図 11b）では，探査範囲西部の急斜面 と, 探查範囲中央〜東部の緩斜面で特徵づけられ る。中央北部で，地表面（図 11a）ではとくに大 きな起伏はないのに対して, 礫層上面である $\mathrm{B}$ 面（図 11b）では北～北北東へ流下する谷の形状 がみられる。しかし，その他ではとくに大きな違 いはなく，地表面（図 11a）と礫層上面（図 11b) は，標高は異なるがほぼ同様の 3 次元形状を示 しているといえる。土䁃・レス層の層厚分布（図 11e）をみても，ほとんどの範囲で層厚は $1.5 〜$ $2.5 \mathrm{~m}$ の幅に収まっており, 地表面（土壤・レス 層上面）と砂層上面（土壤・レス層下面）の形状 には顕著な違いはないといえる。中央北部の B 面の谷状の部分（図 11b）と, 中央南部の地表面 が少々盛り上がっている部分 (図 11a) で, 土壤・ レス層がやや厚くなっている（図 11e）。

次に，基盤岩上面である $\mathrm{C}$ 面（図 11c）では， 探査範囲全域にわたってほぼ一様な傾斜で東側 (海側) へ向かって標高を減ずるが，その傾斜は 地表面（図 11a）やB面（図 11b）に比べると 非常に緩やかである。最終的な判断のためにはよ り多くの情報が必要であるが, 探査地域周辺の環
境と探査結果でみられた特徵から考えると， C 面 は波食棚として形成された可能性が高い。なお, 探査範囲の北西部で小規模な谷・尾根地形や目玉 状の凹地がみられるが，この範囲は V 章 1) 節で 述べた不均質な構造がみられる場所なので注意が 必要である。ただし，このような小規模な谷・尾 根地形や目玉状の凹地が実際の C 面の形状だっ たとしても，C面が波食棚であったならば，海食 甌穴・波食溝・ベンチ内縁凹地などとして形成さ れたことを示唆している可能性がある。また, こ のような特徵をもつ C 面を埋める礫層の層厚分布 は図11fのようになっており，探査範囲東部・中 部では層厚 $2 \mathrm{~m}$ 前後であるのに対して, 探査範囲 西端部付近では西側（山側）へ向かって急激に層 厚を増している。これは探査範囲西端付近の崖錐 堆積物（II 章 2) 節）を示すものと考えられる。

このような面形状から，海成段丘の内縁の標高 を読み取り，旧汀線高度の推定を試みる。一般的 に海成段丘の内縁にあたる旧汀線は，かつての海 水準を示し, 海岸地域における上下変動を明らか にするための重要な地形とされている（例えば, 太田ほか, 2010)。そこで海成段丘の内縁の標高 を，この内縁と直交する探査測線 HS-7, HS-6, HS-5（北から南へ順にあげた）に沿った地形断 面から読み取った（図 12）。すると，それらの標 高は $32 \sim 34 \mathrm{~m}$ となる。地表面の等高線図（図 $11 \mathrm{a}, \mathrm{d})$ でも，標高 $32 \sim 34 \mathrm{~m}$ に相当する場所 はちょうど，西部の急傾斜面と中央〜東部の緩傾 斜面との傾斜変換線にあたる。ただし，図 12 の 地形断面左側・図 $11 \mathrm{a}$ の地表面等高線図左側の 急傾斜面の基部付近は崖錐であることから，より 正確な旧汀線指標としては, 地表で認識できる海 成段丘内縁よりもさらに内陸側の，海成段丘の延 長と海食崖の延長が交差する汀線アングルでの高 度を求めるべきである。しかしそもそも, 図 $11 \mathrm{e}$ からわかるように，本探査地域では場所によって 厚さが不均質な層厚 $1 \sim 3 \mathrm{~m}$ 程度の土壌・レス 層によって覆われているため, 地表面から正確な 旧汀線高度を把握することは難しいと考えられ る。

そのため, 崖錐堆積物だけでなく土壌・レス層 
(a)

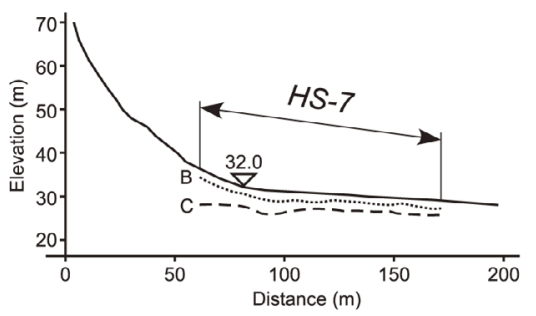

(b)

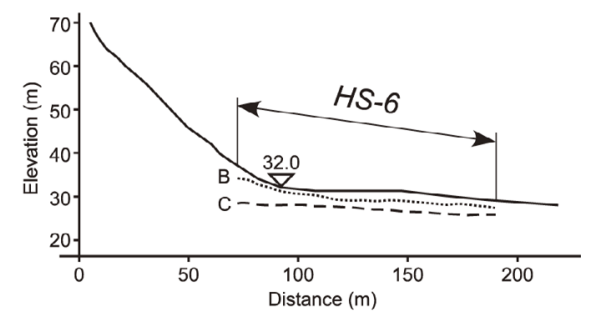

(c)

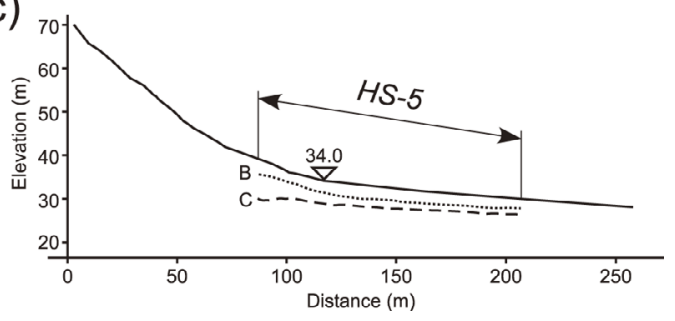

図 12 地形断面から求めた海成段丘の内縁の高度. 逆三角形印は内縁の位置・高度を示す。実線 が地表面, 点線が $\mathrm{B}$ 面, 破線が $\mathrm{C}$ 面をあら わす。（a）HS-7 測線に沿った地形断面.（b） HS-6 測線に沿った地形断面. (c) HS-5 測線 に沿った地形断面.

Fig. 12 Elevations of marine terrace inner-edges inferred from topographic sections. Inverted triangles show locations and elevations of inneredges on sections. Solid lines, dotted lines, and broken lines show ground surface, horizon B, and horizon C, respectively. (a) Topographic section along line HS-7. (b) Topographic section along line HS-6. (c) Topographic section along line HS-5.

なども含めた被覆層を取り除いて，埋没面である B 面や C 面で考えた方がよい。そこでまず，礫 層上面にあたる $\mathrm{B}$ 面（図 11b）の形状をみると, 北部では HS-1 測線のやや西方に並行する標高 $30 \mathrm{~m}$ の等高線が, 南部では HS-1 測線とわずか に斜交する標高 $31 \mathrm{~m}$ および $32 \mathrm{~m}$ の等高線が, 西部の急斜面と中央〜東部の緩傾斜面の境界とな
る傾斜変換線にあたる。よって，本探査地域で土 壤・レスの影響を取り除いた段丘内縁の高度は, 地表面で求めた高度よりも数 $\mathrm{m}$ 低く見積もられ る。

また，基盤上面にあたる C 面（図 11c）が波食 棚として形成されたとした場合，その最も内縁に あたる海食崖基部付近の高度は過去の海水準をよ りよく示すものと考えられる。今回得られた C 面 の範囲では西側の急傾斜面の形状が不明瞭である が，中部〜東部に広がる標高 $26 \sim 28 \mathrm{~m}$ 前後の 緩傾斜面から考えると, 波食棚内縁の傾斜変換線 の高度は $28 \sim 29 \mathrm{~m}$ 前後であると推測される。

以上, 各面の内縁から求められる旧汀線高度 について概察したが，地表面，B面，C面のどれ を基準面として求めるかによってそれぞれ，標高 $32 \sim 34 \mathrm{~m}$, 標高 $30 \sim 32 \mathrm{~m}$ 前後, 標高 $28 \sim$ $29 \mathrm{~m}$ 前後と異なってくる。本研究は地中レーダー 探査による浅部地下地質構造・埋没地形面の検出 までを行ったが，それによって得られた高度の地 形地質学的な信頼度までは言及しない。それにつ いては，各基準面の年代や成因を，さらに詳細な 地形・地質調査で明らかにした上で議論すること が望ましいからである。そして，本研究で明らか になった高度デー夕を用いて, 尻屋崎地域の上下 地殼変動について議論することは, 今後の課題と したい。本研究ではとくに, 連続的な断面情報と なる地中レーダー探査によって，レスの基底面 （礫層上面）や過去の波食棚の可能性がある基盤 岩上面といった，埋没地形面を定量的に評価でき た意義は大きいと考えられる。

\section{VI. 結 論}

下北半島尻屋崎の海成段丘の内縁付近におい て，インパルス地中レーダー探査およびステップ 式連続波地中レーダー探査をそれぞれ 9 測線で 実施した。それにより，インパルス地中レーダー 探査では地表下深度約 $5 \mathrm{~m}$, ステップ式連続波地 中レーダー探査では地表下深度約 $8 \mathrm{~m}$ 程度まで の浅部地下地質構造をイメージングした。

各地中レーダー探査深度変換断面の地質学的 解釈を行い, 土壤・レス層と砂層との境界面 $(\mathrm{B}$ 
面）および，礫層と基盤岩との境界面（C 面）の 断面形状を明らかにした。また， B 面と C 面の それぞれについて 3 次元形状を明らかにした。B 面は地表面とほぼ同様の傾斜で海側へ向かって標 高を減じていた。また，C 面は地表面や B 面に 比べると傾斜が大変緩やかであった。このような 3 次元形状の特徵と探査測線周辺の環境から, 基 盤岩上面（C 面）は過去の波食棚を示している可 能性が考えられる。

旧汀線高度を示す可能性のある指標として，B 面， C 面の内縁高度を求めたところ, それぞれ, 標高 $30 \sim 32 \mathrm{~m}$ 前後, 標高 $28 \sim 29 \mathrm{~m}$ 前後となっ た。これらは，地表面から求めた海成段丘内縁の 高度（標高 $32 ３ 4 \mathrm{~m}$ ）に比べて低い。

本研究では連続的な断面情報となる地中レー ダー探査によって，広がりをもった浅部地下構造 の検出に成功し，レスの基底面（礫層上面）や過 去の波食棚（基盤岩上面）といった埋没地形面に ついて定量的な検討を行うことができた。

\section{謝 辞}

探查の実施に際しては，探查測線にあたる青森県東 通村尻屋地区の土地・道路所有者抒よびその使用者を はじめとする関倸者の皆様に，探查の現場作業への御 協力・御理解をいただいた。3 次元の面形状の作成に あたっては, (独) 産業技術総合研究所地質情報研究部 門の川烟大作氏, 同研究所活断層・地震研究センター (現：活断層・火山研究部門）の竿本英貴氏に助言を いただいた。一部の図の作成には Generic Mapping Tools（Wessel and Smith, 1998）を使用した。本研究 には中田・今泉 (2002) の活断層シェイプファイル（製 品シリアル番号：DAFM0732）を使用した。本研究は, 原子力安全基盤機構「平成 23 年度 沿岸 · 伏在断層の 活動性評価手法の整備」の一環として行われた。また, 本稿は 2 名の匿名查読者による有益な御意見・御指摘 によって改善された。以上，ここに記して，関係者の 皆様に御礼申し上げます。

\section{文献}

Bassinot, F.C., Labeyrie, L.D., Vincent, E., Quidelleur, X., Shackleton, N.J. and Lancelot, Y. (1994): The astronomical theory of climate and the age of the Brunhes-Matuyama magnetic reversal. Earth and Planetary Science Letters, 126, 91-108.
物理探査学会編（1998）: 物理探査ハンドブック．物理 探查学会. [Society of Exploration Geophysics of Japan ed. (1998): Butsuti-Tansa Handbook. (in Japanese) ]

Daniels, D.J. ed. (2007): Ground Penetrating Radar 2nd Edition. Institution of Engineering and Technology.

Davis, J.L. and Annan, A.P. (1989): Ground-penetrating radar for high-resolution mapping of soil and rock stratigraphy. Geophysical Prospecting, 37, 531-551.

Etienne, S. and Paris, R. (2010): Boulder accumulations related to storms on the south coast of the Reykjanes Peninsula (Iceland). Geomorphology, 114, $55-70$

Iizuka, K., Freundorfer, P., Wu, K.H., Mori, H., Ogura, H. and Nguyen, V. (1984): Step-frequency radar. Journal of Applied Physics, 56, 2572-2583.

池田安隆 (2012): 下北半島沖の大陸棚外縁断層：地下 に横たわる巨大な断層を原発安全審査はどうあつ かったのか. 科学, 82, 644-650. [Ikeda, Y. (2012): An active fault at the continental-shelf margin of the Shimokita Peninsula: How did the Nuclear Safety Commission evaluate seismic hazards from the large-scale fault extending down-dip beneath nuclear facilities?. Kagaku, 82, 644-650. (in Japanese) ]

笠井弘幸・阿部信太郎・鈴木浩一 (1996): 活断層の地 中レーダ法によるイメージング：その現状と展望. 活断層研究, 15, 73-86. [Kasai, H., Abe, S. and Suzuki, K. (1996): The imaging of active faults with ground penetrating radar and current problems in its imaging process. Active Fault Research, 15, 73-86. (in Japanese with English abstract) ]

活断層研究会編 (1991): 新編日本の活断層一分布図と 資料一. 東京大学出版会. [Research Group for Active Fault of Japan ed. (1991): The Active Fault in Japan: Sheets Maps and Inventories, Rev. edition. University of Tokyo Press. (in Japanese with English abstract) ]

岸本清行 (2000): 海陸をあわせた日本周辺のメッシュ 地形デー夕の作成：Japan $250 \mathrm{~m}$.grd. 地質調査所 研究資料集. No. 353, 地質調査所. [Kishimoto, K. (2000): Combined Bathymetric and Topographic Mesh Data: Japan250m.grd. Geological Survey of Japan Open File Report. No. 353, Geological Survey of Japan. (in Japanese) ]

小池一之・町田 洋編 (2001): 日本の海成段丘アトラ ス. 東京大学出版会. [Koike, K. and Machida, H. eds. (2001): Atlas of Marine Terraces of Japanese Island. University of Tokyo Press. (in Japanese) ]

熊木洋太・鈴木美和子・小原 昇編（1995）：技術者の ための地形学入門. 山海堂. [Kumaki, Y., Suzuki, M. and Obara, N. eds. (1995): Geomorphology for Engineers (Gijutsusha No Tameno Chikeigaku). Sankaido. (in Japanese)*]

松岡 篤 (1987): 青森県尻屋層群の放散虫年代. 化石, 42, 7-13. [Matsuoka, A. (1987): Radiolarian age 
of the Shiriya Group in Aomori Prefecture, northeast Japan. Fossils, 42, 7-13. (in Japanese with English abstract) ]

Matsu'ura, T., Kimura, H., Komatsubara, J., Goto, N., Yanagida, M., Ichikawa, K. and Furusawa, A. (2014): Late Quaternary uplift rate inferred from marine terraces, Shimokita Peninsula, northeastern Japan: A preliminary investigation of the buried shoreline angle. Geomorphology, 209, 1-17.

宮内崇裕（1990）: 旧汀線高度からみた東北日本弧北部 の広域地殼変動. 米倉伸之・岡田篤正・森山昭雄 編：変動地形とテクトニクス. 古今書院, 157-169. [Miyauchi, T. (1990): Late Quaternary regional tectonism of the northern Northeast Japan Arc, deduced from paleoshoreline height. in Tectonic Landforms edited by Yonekura, N., Okada, A. and Moriyama, A., Kokon Shoin, 157-169. (in Japanese)]

中田高・今泉俊文編 (2002): 活断層詳細デジタルマッ プ. 東京大学出版会. [Nakata, T. and Imaizumi, T. eds. (2002): Digital Active Fault Map of Japan. University of Tokyo Press. (in Japanese)]

Neal, A. (2004): Ground-penetrating radar and its use in sedimentology: principles, problems and progress. Earth-Science Reviews, 66, 261-330.

Ota, Y. (1975): Late Quaternary vertical movement in Japan estimated from deformed shorelines. Quaternary Studies, Bulletin, Royal Society of New Zealand, 13, 231-239.

太田陽子 - 小池一之・鎮西清高 - 野上道男 - 町田 洋 · 松田時彦 (2010): 日本列島の地形学. 東京大学出版 会. [Ota, Y., Koike, K., Chinzei, K., Nogami, M., Machida, H. and Matsuda, T. (2010): Geomorphology of the Japanese Islands. University of Tokyo Press. (in Japanese) ]

Sheriff, R.E. and Geldart, L.P. (1995): Exploration Seismology 2nd Edition. Cambridge University Press.

Siddall, M., Chappell, J. and Potter, E.K. (2006) : Eustatic sea level during past interglacials. in The
Climate of Past Interglacials edited by Sirocko, F., Claussen, M., Sanchez Goñi, M. F. and Litt, T., Elsevier, 75-92.

Smith, D.G. and Jol, H.M. (1995): Ground penetrating radar: Antenna frequencies and maximum probable depth of penetration in Quaternary sediments. Journal of Applied Geophysics, 33, 93-100.

鈴木敬一・笠井弘幸・西山英一郎 (1999): ステップ式 連続波レーダ探査装置を用いた地中レーダ探査. 地 質ニュース，537，44-52. [Suzuki, K., Kasai, H. and Nishiyama, E. (1999): Ground penetrating radar exploration by the stepped continuous wave radar system. Chisitsu News, 537, 44-52. (in Japanese)]

対馬坤六・滝沢文教（1977）：尻屋崎地域の地質，地 域地質研究報告 (5 万分の 1 図幅). 地質調査所. [Tsushima, K. and Takizawa, F. (1977): Geology of the Shiriyazaki District, Quadrangle Series 1:50,000. Geological Survey of Japan. (in Japanese with English abstract) ]

脇田浩二・井川敏恵・宝田晋治編 (2009): 20 万分の 1 日本シームレス地質図 DVD 版, 数值地質図 G-16. 産業技術総合研究所地質調査総合センター。 [Wakita, K., Igawa, T. and Takarada, S. eds. (2009): Seamless Geological Map of Japan at a Scale of 1:200,000 DVD edition, Degital Geoscience Map G-16. Geological Survey of Japan, AIST.]

渡辺満久 · 中田 高・鈴木康弘 (2008): 下北半島南部 における海成段丘の撓曲変形と逆断層運動. 活断層 研究, 29, 15-23. [Watanabe, M., Nakata, T. and Suzuki, Y. (2008): Active reverse faulting deduced from flexural deformation of marine terraces around southern area of the Shimokita Peninsula, northeast Japan. Active Fault Research, 29, 15-23. (in Japanese with English abstract) ]

Wessel, P. and Smith, W.H.F. (1998): New, improved version of the Generic Mapping Tools released. EOS Transactions AGU, 79, 579.

* Title etc. translated by H.K. 